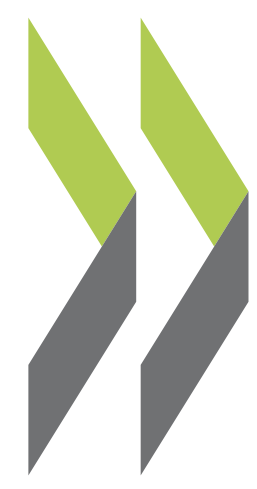

OECD Economics Department Working Papers No. 509

Regulation, Competition and Productivity Convergence

Paul Conway,

Donato de Rosa,

Giuseppe Nicoletti,

Faye Steiner 
Organisation de Coopération et de Développement Economiques

Organisation for Economic Co-operation and Development

04-Sep-2006

ECONOMICS DEPARTMENT

English text only

REGULATION, COMPETITION AND PRODUCTIVITY CONVERGENCE

ECONOMICS DEPARTMENT WORKING PAPERS No. 509

By

Paul Conway, Donato de Rosa, Giuseppe Nicoletti and Faye Steiner

All Economics Department Working Papers are available through OECD's internet web site at www.oecd.org/eco/working_papers. 


\section{ABSTRACT/RESUMÉ \\ Regulation, Competition and Productivity Convergence}

This paper investigates the effect of product market regulations on the international diffusion of productivity shocks. The empirical results indicate that restrictive product market regulations slow the process of adjustment through which best practice production techniques diffuse across borders and new technologies are incorporated into the production process. This suggest that remaining cross-country differences in product market regulation can partially explain the recent observed divergence of productivity in OECD countries, given the emergence of new general-purpose technologies over the 1990s. The paper also investigates two channels through which product market regulations might affect the international diffusion of productivity shocks, namely the adoption of information and communications technology and the location decisions of multi-national enterprises. In both cases the effect of anticompetitive product market regulation is found to be negative and significant.

JEL codes: O11, O33, O40, O47, C33

Keywords: Productivity convergence; Institutions and growth; Information and communication technologies; Foreign direct investment; Panel data analysis.

\section{$* * * * *$ \\ Régulation, concurrence et convergence de la productivité}

Cette étude analyse les effets de la régulation dans les marchés des biens sur la diffusion des chocs de productivité au niveau international. Les résultats empiriques indiquent que les restrictions dans les marchés des biens ralentissent le processus d'ajustement à travers lequel les techniques de production les plus avancées se répandent au-delà des frontières et sont incorporées dans l'activité productive. Ces résultats suggèrent que les différentes approches dans la régulation des marchés des biens qui caractérisent encore les pays de l'OCDE peuvent expliquer en partie la tendance à la divergence des niveaux de productivité qui a été observée récemment dans la zone OCDE, étant donné l'émergence des nouvelles technologies de l'information et communication au cours de la même période. L'étude analyse aussi deux canaux par lesquels la régulation peut influencer la diffusion des chocs de productivité au niveau international: l'investissement en nouvelles technologies de l'information et communication et les décisions de localisation des filiales des entreprises multinationales. Dans les deux cas, les résultats suggèrent que l'effet des régulations qui font obstacle à la concurrence dans les marchés des biens est négatif et significatif.

Codes JEL : O11, O33, O40, O47, C33

Mots clés : Convergence de la productivité; Institutions et croissance; Technologies de l'ínformation et communication ; Investissement direct de l'étranger ; Analyse en données de panel.

\section{Copyright OECD, 2006}

Application for permission to reproduce or translate all, or part of, this material should be made to: Head of Publications, OECD, 2 rue André-Pascal, 75775 Paris Cedex 16, France. 


\section{TABLE OF CONTENTS}

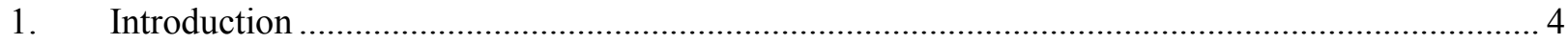

2. Product market regulation and labour productivity in the OECD: convergence and divergence?.. 6

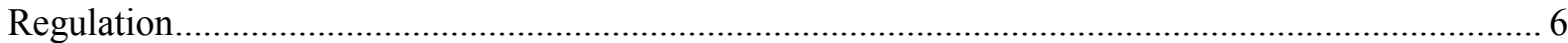

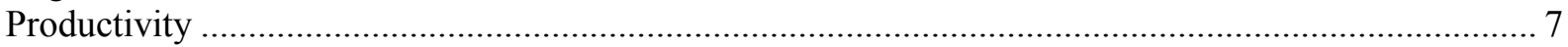

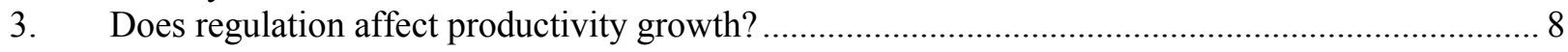

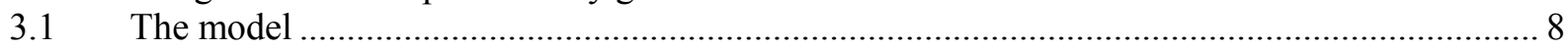

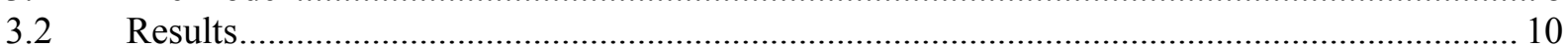

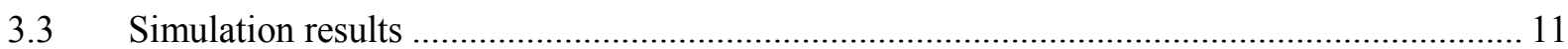

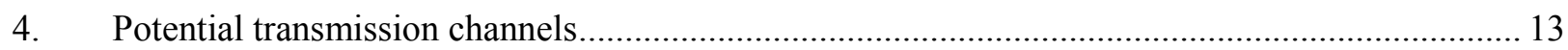

4.1 The effect of product market regulation on ICT investment................................................... 13

4.2 The effect of product market regulation on the location decisions of foreign affiliates ........... 16

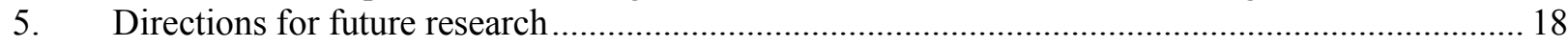

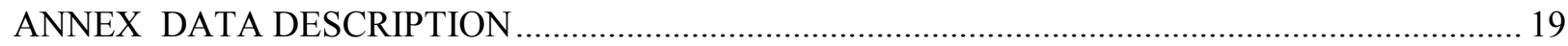

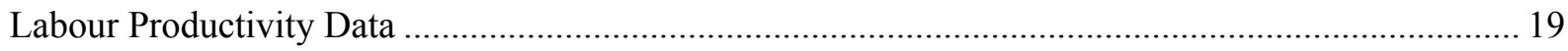

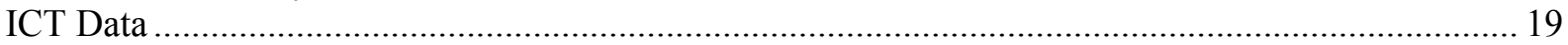

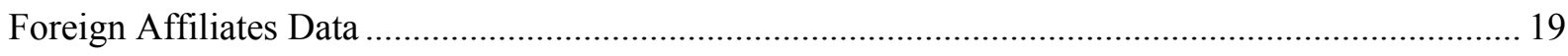

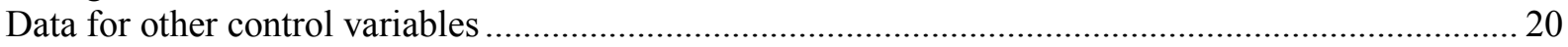

The classification of ICT-producing, ICT-using, and non-ICT intensive sectors ................................ 20

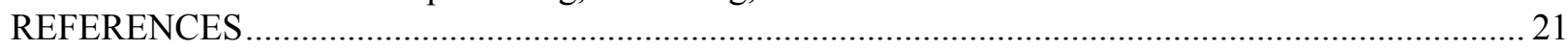

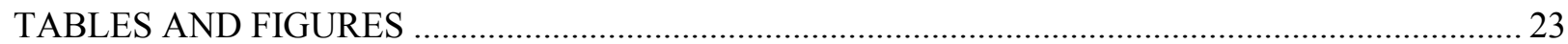




\title{
REGULATION, COMPETITION AND PRODUCTIVITY CONVERGENCE ${ }^{1}$
}

\author{
Paul Conway, Donato De Rosa, Giuseppe Nicoletti, Faye Steiner
}

\section{Introduction}

1. Product market regulation in the OECD area has generally become less restrictive of competition over recent years. This has lead to a degree of convergence in regulatory policies, but nonetheless the productivity performance of OECD countries has become increasingly disparate. Indeed, according to some measures, the growth rates and levels of labour productivity have recently begun to diverge. Recent developments in the theory and empirics of growth suggest that cross-country productivity patterns may partly reflect differences in the policy and institutional environment (Acemoglu et al., 2004; Aghion and Griffith, 2005).

2. Against this background, this paper investigates the link between anti-competitive product market regulations and the international diffusion of productivity shocks using a productivity model that relates productivity growth to improvements in the global technology frontier and the speed of the catch up process (Griffith et al., 2004). As well as looking at the prima facie evidence of a link, the paper also investigates two channels through which regulations that curb competition might affect the diffusion of best practice production techniques. In particular, building on the work of Gust and Marquez (2004) and Nicoletti et al. (2003) the influence of anti-competitive regulation on the adoption of information and communications technology (ICT) and the location decisions of multi-national enterprises is assessed. Depending on data availability, the analysis is conducted at both the aggregate business sector and sectoral levels.

3. The empirical results indicate that restrictive product market regulation slows the process of adjustment through which positive productivity shocks diffuse across borders and new technologies are incorporated into the production process. In some of the more restrictive OECD countries the loss of adaptability that occurs as a result of anti-competitive regulation can be sizeable. For example, estimates suggest that the improvement in domestic labour productivity that arises in these countries as a result of a one-off positive shift in the world productivity frontier can be up to $25 \%$ smaller than in a country in which product market regulation in non-manufacturing sectors is the least restrictive in the OECD. In all the countries included in the study the detrimental effect of anti-competitive regulation is larger in sectors that product or use ICT intensively. This is because the regulatory barriers to diffusion tend to be higher in these sectors in comparison to the rest of the economy. As a result, the gap in productivity improvement in restrictive countries following a shift in the world productivity frontier can be as high as $40 \%$ in these sectors, relative to the most liberal countries.

4. Because relatively liberal countries benefit from improvements in the world productivity frontier more quickly than countries with more restrictive policy regimes, the cross-country dispersion of productivity levels is found to increase in the wake of a positive global productivity shock. In times of rapid improvements in the productivity frontier the positive effect of pro-competitive regulations on the speed of catch-up is amplified, increasing the dispersion of productivity levels across countries in which the stringency of product market regulation differs. These results imply that the emergence of new general-

1 We would like to thank Jorgen Elmeskov, Mike Feiner, and OECD country representatives at the Spring 2006 meeting of the Working Party 1 of the OECD Economic Policy Committee for useful comments on an earlier version of this paper. The views expressed in the paper are the authors' own and do not necessarily reflect those of the OECD or its Member countries. 
purpose technologies over the 1990s could partially explain divergent productivity trends, despite a degree of recent convergence in product market regulation across countries.

5. The results of simulating the productivity model suggest that the gains from further product market reform may be considerable, especially in countries that operate at some distance from the world productivity frontier. For example, over the period of the ICT shock (1995 to 2003), if OECD countries had aligned regulation in non-manufacturing sectors on that of the least restrictive OECD country, the increase in annual productivity growth due to faster catch-up is estimated to range from 0.2 percentage points in the United Kingdom - which has one of the least restrictive regulatory environments according to OECD indicators - to 1.8 percentage points in Greece. In a number of countries, the average increase in annual productivity growth over this period given a liberal regulatory environment is estimated to be greater than 0.75 percentage points, implying substantial long-run gains in the level of productivity and a continuation of the process of productivity convergence. The gains from further product market reform are estimated to be largest in ICT-intensive sectors, where product market regulation is also found to have a direct impact on labour productivity growth.

6. The analysis in the second part of the paper finds that the link between product market regulation and productivity catch up can be traced to two factors. Overall, product market regulation is found to be a significant determinant of investment in ICT, with relatively liberal countries more successful at incorporating ICT into the production process than relatively restrictive countries. In the United States since the mid-1990s, for example, ICT investment as a share of total investment is estimated to have been more than four percentage points above the OECD average of $15 \%$ as a direct result of the relatively liberal regulatory environment. On average across countries for which data exist, estimates suggest that ICT investment as a share of total investment would increase by around 2.5 percentage points if countries adopted the regulatory stance of the least restrictive OECD country in each sector. For some countries the additional investment in ICT that would result from such a move represents a substantial increase in the existing stock.

7. Confirming previous findings (Nicoletti et al., 2003) there is also evidence that a restrictive regulatory stance curbs the establishment of foreign affiliates of multinationals, which is also likely to inhibit the international diffusion of technology. Ongoing reform of product market and foreign direct investment regulation is estimated to considerably increase the activity of foreign affiliates in some countries.

8. The rest of the paper is structured as follows. Section 2 briefly outlines recent developments in product market regulation and labour productivity in the OECD area. Section 3 presents the model that is used to test the influence of product market regulation on productivity growth, the results of the estimation, and some illustrative simulations. In Section 4 additional panel data regressions are used to investigate the effect of product market regulation on the two potential transmission channels mentioned above. A final section suggests some steps for further research in this area. 


\section{Product market regulation and labour productivity in the OECD: convergence and divergence $^{2}$}

\section{Regulation}

9. In the empirical work that follows two sets of indicators are used to measure product market regulation at the economy-wide and sectoral levels respectively:

- An aggregate indicator of regulatory conditions in seven non-manufacturing sectors - covering transport (airlines, railways, road freight), energy (gas, electricity), and communications (post, and telecoms) - is used as a proxy for economy-wide product market regulation. While this indicator misses important aspects of economy-wide regulation, it includes some of the sectors in which anti-competitive regulation is concentrated in OECD countries, given that manufacturing sectors are typically lightly regulated and open to international competition. In addition, this indicator is highly correlated with the cross-section indicator of economy-wide product market regulation in the years in which they overlap, suggesting that the former is a reasonable proxy for the latter. ${ }^{3}$ The indicators for the seven non-manufacturing sectors have been estimated for 21 OECD countries over the period 1975 to 2003 and are therefore well suited to time-series analysis. ${ }^{4}$

- The time series indicators of anti-competitive regulation discussed above, as well as cross-section indicators of regulatory conditions in retail distribution, banking, and business services are used to compute indicators of the 'knock-on' effects of regulation at the sectoral level. These indicators, called the regulation impact indicators, are predicated on the notion that anti-competitive regulations in non-manufacturing sectors not only have a direct influence on market conditions in these sectors, but also have a less visible impact on the cost structures faced by firms that use the output of non-manufacturing sectors as intermediate inputs in the production process. ${ }^{5}$ This is especially the case given the large and increasingly important role of the non-manufacturing sector as a supplier of intermediate inputs in OECD countries over recent years. For each sector in a particular country the regulation impact indicator is calculated as a weighted average of the indicators of regulation in non-manufacturing sectors. The weights used in the calculation are total input coefficients, derived from (harmonised) input-output tables, which measure the extent to which intermediate inputs from each of the non-manufacturing sectors are used in the final output of each sector in the economy. Hence, the regulation impact indicators are a measure of the degree to which each sector in the economy is exposed to anti-competitive regulation in non-

2 This section provides only a very brief summary of trends in product market regulation and productivity in OECD countries. For more on the construction of the indicators used to measure anti-competitive regulation and patterns of regulatory reform in OECD countries see Conway and Nicoletti (2006). Trends in productivity in OECD countries are discussed in detail in a number of sources including OECD (2003a).

3 The economy-wide indicators of product market regulation in OECD countries are described in Conway et al. (2005) and Nicoletti et al. (1999).

4 These countries are: Australia, Austria, Belgium, Canada, Denmark, Finland, France, Germany, Greece, Ireland, Italy, Japan, Netherlands, New Zealand, Norway, Portugal, Spain, Sweden, Switzerland, the United Kingdom, the United States.

5. As well as intermediate inputs, the 'knock-on effects' of regulation in non-manufacturing sectors will also propagate through the economy via a number of other channels such as the effect on the price of investment goods and "Baumol disease" effects that act through wages. In this context, focusing on the role of non-manufacturing sectors as suppliers of intermediate inputs provides only a lower bound to these propagation effects. It does, however, facilitate their empirical measurement, which is important in the context of the analysis that follows. 
manufacturing sectors. These indicators exist for 39 ISIC rev3 sectors in 21 OECD countries over the period 1975 to 2003 .

10. According to the aggregate indicators of regulation in transport, energy, and communications sectors, product market regulation has become more conducive to market mechanisms in the OECD area in recent years as governments have liberalised potentially competitive markets, re-regulated natural monopoly markets establishing pro-competitive regulation where possible, and privatised previously stateowned assets. Given different starting points and patterns of reform, cross-country differences in the stance of product market regulation increased across the OECD in the 1980s and 1990s (Figure 1). From the late1990s, however, the dispersion in policy stance has fallen in part because regulation in the Euro area and former transition countries has moved towards that of the more liberal countries. Notwithstanding this convergence, however, product market regulation in the OECD area is still characterised by significant differences across countries (Conway et al., 2005).

\section{[Figure 1: Evolution and dispersion in regulatory environments, 1980-2003]}

11. One feature of the sectoral regulatory indicators that is germane for the empirical results that follow is that the knock-on effects of anti-competitive regulation in non-manufacturing sectors is typically largest in sectors in which ICT equipment is used intensively (Figure 2). This reflects the fact that these sectors tend to be more exposed to anti-competitive regulation in non-manufacturing sectors relative to other sectors. The impact of regulation on ICT-using sectors is particularly high in many continental EU countries, Japan, and Canada. In addition, the cross-country variation in the regulation impact indicators is also largest in ICT-using sectors.

\section{[Figure 2: The impact of regulation in ICT-producing, ICT-using, and non-ICT intensive sectors, 2003]}

\section{Productivity}

12. In the empirical work that follows, labour productivity at the aggregate level is calculated as the ratio of business sector GDP to business sector employment, while at the sectoral level labour productivity is calculated as value added per person employed in each industry. ${ }^{6}$ To ensure comparability across countries, the output values used to estimate labour productivity are converted into prices denominated in a common currency using purchasing power parities (PPP). For both the sectoral and business sector productivity estimates this has been done using aggregate PPPs. ${ }^{7}$

6 Cross-country differences in labour productivity reflect differences in technology in its broadest possible sense including differences in capital intensity, capital quality, human capital, economies of scale, and intangibles such as management techniques. Estimates of multi-factor productivity (MFP) account for some of these additional factors by relating a measure of output to a bundle of productive inputs, making it a more precise estimate of productive efficiency. However, given difficulties inherent in measuring the capital stock and other productive inputs, estimates of MFP tend to be less robust than those of labour productivity, particularly at the industry level. Labour productivity should ideally be calculated using data on hours worked. However, comprehensive cross-country data on hours worked is only available at the level of the aggregate economy and estimates of labour productivity at lower levels of aggregation must be computed using total employment.

7 Although this implies the assumption of identical comparative price levels across industries, van Biesebroeck (2005) finds that, overall, aggregate PPPs perform as well as sectoral PPPs, where performance is measured as the correlation with sectoral deflation rates. For some service sectors aggregate PPPs are found to perform better than sectoral PPPs, while for some manufacturing sectors sectoral PPPs 
13. As illustrated in detail in OECD (2003a), productivity performances have varied markedly across countries over the past two decades and the process of catch-up has been stalling for several years (Figures 3,4). From 1995 only a few high-growth countries have continued to converge towards the productivity levels of the United States (Figure 5).

\section{[Figure 3: Growth in business sector labour productivity per employee]}

[Figure 4: The standard deviation of labour productivity across countries]

[Figure 5: Change in productivity levels relative to the United States]

14. To some extent these disparities in productivity growth reflect differing degrees of adaptability across countries to recent technology shocks (OECD, 2003b). In the United States a large proportion of the increase in labour productivity in the second half of the 1990s originated in sectors that either produce or intensively use ICT (Figure 6). A few other countries - for example, Ireland, Australia, Finland, Mexico, Portugal, and the United Kingdom - also experienced accelerating productivity growth in these sectors in the second half of the 1990s. In a number of countries, however, the contribution of ICT-producing or using sectors to productivity growth has typically been smaller than in the United States and even declined in several of them over the $1990 \mathrm{~s}^{8}$

[Figure 6: Contributions to aggregate labour productivity growth]

15. Thus, although ICT is a 'general purpose' technology and readily available in worldwide markets, only a limited number of OECD countries have been reaping its significant potential benefits to the full. This hints at the potential role of policy and institutional factors in explaining the differing abilities of countries to produce ICT and integrate these technologies into the production process. It also suggests a potential explanation for the apparent paradox of diverging productivity trends across countries in conjunction with a degree of regulatory convergence. If restrictive product market regulation raises barriers to technology implementation and reduces the incentive to increase efficiency and innovate, it may slow down productivity enhancements related to the production and the adoption of new technologies. Therefore, regulation may have a stronger influence on productivity patterns in times of rapid technological innovation. The emergence of ICT in the second half of the 1990s may have amplified the effect of remaining cross-country differences in anti-competitive regulation, which were still significant. Indeed, at first glance, countries with a relatively liberal approach to competition have tended to experience a greater acceleration in productivity growth after 1995 (Figure 7).

\section{[Figure 7: Product market regulation and labour productivity acceleration]}

\section{Does regulation affect productivity growth?}

\subsection{The model}

16. To test the effect of regulation on catch-up to best practice, a model of labour productivity based on the work of Aghion and Howitt (2005) is estimated at both the aggregate business sector and sectoral levels. In this model labour productivity growth in a given country or sector depends on its ability to keep pace with growth in the country with the highest level of labour productivity (the productivity leader) by

perform marginally better. All of the productivity used is derived from the OECD Productivity and STAN databases. Full details on data sources are provided in the annex.

8. The role of ICT production and use is discussed in detail in Pilat and Wölfl (2004). Differences in the contribution of ICT-using sectors to productivity growth have also been found to be important sources of productivity divergence between the United States and Europe. See, for example, van Ark et al., (2002). 
either innovating or taking advantage of technology transfers. In turn, this possibility is affected by the policy environment in follower countries or sectors. In particular, Aghion and Griffith (2005) stress the role played by institutions that promote (or hinder) firm rivalry and/or entry of new firms in raising (or curbing) incentives to enhance productivity. In the model presented here these institutions are proxied by the OECD indicators of anti-competitive regulations described earlier. The estimated equation is: ${ }^{9}$

$$
\begin{aligned}
\begin{aligned}
\Delta \ln L P_{i j t}= & \delta\left(\Delta \ln L P_{i j t}^{\text {leader }}\right)+\sigma\left(\operatorname{prodgap}_{i j t}\right)+\gamma P M R_{i j t}+\alpha\left(P M R_{i j t} * \operatorname{prodgap}_{\mathrm{ijt}}\right)+ \\
& +X_{i j}^{\prime} \beta+\text { country/industry/time dummies }+\varepsilon_{i j t} \\
& \quad \varepsilon \sim N(0, \Sigma)
\end{aligned} \\
\text { with } \quad
\end{aligned}
$$

17. In this equation, the indices $i, j$ and $t$ denote countries, industries and years, respectively; LP denotes labour productivity; prodgap is the 'productivity gap' - which is measured as the (log) ratio of the level of productivity in each country or sector relative to that of the productivity leader - and $P M R$ is the appropriate indicator of anticompetitive product market regulation. The matrix $X$ contains various control variables. Country, industry, and country-industry fixed effects are included as appropriate so as to account for unobserved time-invariant factors affecting productivity growth in a particular sector or country (e.g., natural endowments or location). Time dummies are also included to control for global productivity shocks in any given year.

18. In this model labour productivity shocks in the leader country or sector can have a direct effect on labour productivity growth in follower countries, the strength of which is measured by the coefficient $\delta$. In addition, this equation also allows for the possibility that the difference in productivity levels between each country or sector and the productivity leader influences labour productivity growth. If the coefficient $\sigma$ is negative and significant then the further a given country or sector is from the technological frontier the greater the scope for productivity improvements arising from technological catch up. Clearly, the higher is $\sigma$ (in absolute value) the faster is such catch up process.

19. Product market regulation can influence labour productivity growth directly - the strength of which is measured by the coefficient $\gamma$ - and indirectly by affecting the speed with which countries catch up to the productivity leader. This indirect channel is included in the model by allowing regulation to interact with the technology gap term. This allows for the possibility that by creating barriers to entry or hindering competition amongst incumbents, anti-competitive regulation may reduce incentives to invest and adopt leading production techniques, thereby lowering the speed with which countries/sectors catch up to the productivity leader. A positive and significant value of the coefficient on this term, $\alpha$, implies that more restrictive product market regulation hinders the diffusion of productivity shocks from the productivity leader.

20. Reflecting data availability, the aggregate business sector model is estimated over the period 1978 to 2003 for the subset of 21 OECD countries for which the aggregate indicator of regulation in seven network sectors exists. The sectoral version of the model is estimated for 20 sectors over the period 1981 to 2003 for the same countries except Ireland, given the lack of sectoral productivity data for this country. It is useful to remind at this stage that, in the sectoral model, regulation is proxied by the "regulation impact" indicators described above, which cover both manufacturing and non-manufacturing industries over the sample period.

9 This model is a variant of the model developed by Griffith et al. (2004) to test the effect of R\&D expenditure on productivity growth. It has also been used by Nicoletti and Scarpetta (2003) to investigate the effect of product market regulation on multi-factor productivity growth. 


\subsection{Results}

21. The results of estimating the business sector and sectoral versions of the labour productivity model are given in Table 1. In principle, the influence of capital deepening and factors related to the quality of human and physical capital used in production should already be reflected in the productivity catch up term. However, these factors could also have a direct effect on the ability of an economy (or sector) to respond to shifts in the global productivity frontier. This would be the case, for instance, if a more educated labour force, a higher capital intensity, and/or a deeper familiarity with ICT technologies were to facilitate the transfer of technology from the leader to follower countries. To account for this possibility, we include as control variables proxies for aggregate or sectoral human capital, change in the capital stock per employee, and the share of ICT in total investment. Moreover, we also include the output gap in the aggregate model to account for purely cyclical changes in productivity.

\section{[Table 1: Results of productivity growth regressions]}

22. In terms of these control variables, the output gap, human capital (measured as the average years of education in the population) and, to a lesser extent, the share of ICT investment in total investment are found to significantly influence productivity growth in the business sector version of the model. Growth in the productivity leader becomes insignificant when the ICT-share in included in this regression suggesting that the latter captures the effects of shifts in the productivity frontier. ${ }^{10}$ At the sectoral level, the change in the capital stock per employee has a positive and significant effect on labour productivity growth. The proxy for human capital, however, is insignificant and data for ICT shares by sector is too sparse to be used as a control in these regressions.

23. In both versions of the model, labour productivity growth in the productivity leader is typically found to have a positive and highly significant influence on productivity growth in less productive countries and sectors. In addition, the coefficient on the 'productivity gap' is always negative and highly significant. Thus, the importance of international diffusion of best practice production techniques as a source of productivity growth increases the further a country is from the world technological frontier. These results highlight the important role of catch-up as a driver of productivity growth, reflecting a high degree of economic integration in the OECD area and the fact that technological innovation usually occurs in a given region or country. ${ }^{11}$

24. In both versions of the model, no direct effect of anti-competitive regulation on productivity growth is found in the base regressions. However, when the coefficient on the direct effect of regulation is estimated separately for ICT-intensive (ICT-using and ICT-producing sectors) and non-ICT intensive sectors, there is evidence of a direct negative effect in the former that is significant at the $5 \%$ level. This implies that weak competition is particularly harmful for technology-driven productivity improvements in ICT-intensive sectors. ${ }^{12}$

25. The regulatory environment is also found to exert an important indirect influence on productivity growth by slowing the speed with which countries or sectors catch-up to the productivity leader. The

10. Note, however, that including the share of ICT investment in total investment in the model reduces the number of available observations substantially, impairing the comparability of the two aggregate business sector regressions.

11. Keller (2004) notes that "only a handful of rich countries account for most of the world's creation of new technology" and that in most countries "foreign sources of technology account for $90 \%$ or more of domestic productivity growth".

12. Conway et al. (2006) further explore this issue providing a deeper evaluation of the direct effects of anticompetitive regulation on productivity growth. 
coefficient on the interaction between regulation and the productivity gap is always positive and significant at the $1 \%$ level. These results indicate that well-functioning product markets are an important condition for rapid productivity catch-up, perhaps because they increase the incentive and lower the cost of incorporating new technologies into the production process, as suggested by neo-Schumpeterian growth theories (Aghion and Howitt, 2005). These results are broadly consistent with those of Nicoletti and Scarpetta (2003) who use a similar approach to study the effect of regulation on multi-factor productivity (MFP). ${ }^{13}$ Conway et al., (2006) further explore the implications of neo-Schumpterian growth theories by accounting more systematically for sectoral differences, the distance of countries and sectors from the technological frontier and the effects of different kinds of regulations (e.g., border and non-border barriers to competition).

\subsection{Simulation results}

26. The economic significance of the estimation results reported above can be assessed by simulating the simplest version of the sectoral labour productivity growth model (Table 1B, column 1). These policy simulations are only indicative because they assume that policy changes do not change the estimated average relationships (the Lucas critique) and that these are representative of the relationships in each country (with a possible heterogeneity bias). These simulations may also under-estimate the effect of policies on aggregate productivity to the extent that reform also results in resources moving from relatively unproductive to relatively productive sectors, a possibility that is not accounted for in the sectoral model. ${ }^{14}$ However, the simulation results provide an idea of the order of magnitude of the estimated effects of product market policies on productivity catch up.

27. As a starting point it is useful to use the model to illustrate the effect of current anti-competitive regulations on the diffusion of a global positive productivity shock across OECD countries. To this end, Figure 8 graphs the increase in productivity that would occur in each country five years after a one-off outward shift in the world productivity frontier of an equal magnitude in all sectors. To isolate the effect of product market regulation, this simulation is conducted from a steady-state in which the level of productivity in each sector is assumed to be initially equal across all countries. Thus, the initial shock results in the same sectoral productivity gap in all countries, which then close at different speeds depending on the relative stringency of anti-competitive regulations. The increase in productivity that would arise in response to the shock is expressed as a proportion of the increase that would occur in a country in which product market regulation in non-manufacturing sectors is the least restrictive of competition among OECD countries.

\section{[Figure 8: The effect of regulation on the diffusion of a positive supply shock]}

28. In a few countries - Sweden, Ireland, the Netherlands, Denmark, the United Kingdom, and New Zealand - the influence of anti-competitive regulation on the diffusion of the productivity shock is relatively minor with aggregate productivity increasing by around $95 \%$ of the response in a country with the least restrictive product market regulation. In some of the other countries - notably Austria, Greece, and Italy - anti-competitive regulation implies a greater lack of adaptability in the wake of a positive

13. These authors find that restrictive industry-specific product market regulation in manufacturing tends to reduces MFP growth mainly via the process of technological catch-up. They also find evidence of a direct link between a proxy for economy-wide product market regulation and sectoral MFP growth.

14 In OECD countries, productivity growth within industries has been found to make a relatively large contribution to overall productivity growth in comparison to shifts of employment across industries (OECD 2003a). Given that the reallocation of resources across industries has played a relatively minor role in explaining cross-country differences in aggregate productivity growth, the results that emerge from the sectoral-level model may be generalized to explain aggregate patterns. 
global supply shock with aggregate productivity increasing by around $75 \%$ of the response in a country where product market regulation is least restrictive of competition. As a result the dispersion of productivity levels across countries tends to increase over time following such a shock (Figure 9).

\section{[Figure 9: Standard deviation of labour productivity across countries following a global supply shock: ICT and non-ICT intensive sectors]}

29. In all countries the detrimental effect of anti-competitive regulation is larger in ICT-intensive sectors (ICT-using and ICT-producing sectors) given that, as discussed in Section 2 above, the regulatory barriers to diffusion are estimated to be higher in these sectors in comparison to non-ICT intensive sectors. The estimated gap in productivity catch-up in ICT-intensive sectors is particularly sizeable in Austria, Greece, Italy, Germany, Norway, and Belgium, all of which remain $30 \%$ to $40 \%$ below potential five years after the initial shock. In addition, reflecting larger cross-country heterogeneity in the regulation of ICTintensive sectors, the dispersion of productivity levels across countries is also larger in these sectors following an improvement in the productivity frontier of an equal magnitude in all sectors.

30. To assess the productivity dividend from faster convergence to the world productivity leader given further reform of product market regulation the steady state assumption is dropped and the model is simulated within sample from 1995 to 2003 on the basis of the cross-country productivity gaps that prevailed over this period. The benchmark for regulatory reform used in these simulations is the implementation of the regulatory settings of the country with the lowest level of anti-competitive regulation in each of the seven non-manufacturing sectors included in the regulatory indicator. This, of course, tends to lower the "regulatory impact" indicators in other sectors, as well, to an extent that depends in each country from the initial level of regulation and the composition of intermediate inputs. For some OECD countries this reform package would be considered ambitious as it would involve an easing of domestic product market regulation to levels that are less restrictive than present policy settings in any OECD member country. However, in the context of recent substantial improvements in product market regulation, this reform package would constitute a continuation of the trend to liberalise product markets, as opposed to a radical shift in policy stance.

31. In this scenario the productivity dividend from product market reform in each year in a given country depends on both the distance from the productivity leader in each sector and the extent of anticompetitive regulation relative to the least restrictive country. The average increase in annual productivity growth over the period 1995 to 2003 given regulatory reform ranges from 0.2 percentage points for the United Kingdom to 1.8 percentage points for Greece (Figure 10). In some of the other Continental EU countries - Portugal, Spain, Germany, Italy, Austria, and France - and Norway and Canada the increase in annual productivity growth is more than 0.75 percentage points. In all countries except Finland and Sweden the gains from product market liberalisation are greatest in ICT-intensive sectors, once again reflecting the greater exposure to anti-competitive regulation in these sectors (Figure 11).

[Figure 10: Increase in average annual business sector productivity growth over the period 1995 to $\mathbf{2 0 0 3}$ given a move to sectoral regulations that are least restrictive of competition in 1995]

\section{[Figure 11: Increase in average annual productivity growth over the period 1995 to 2003 given a move to sectoral regulations that are least restrictive of competition: ICT-intensive and non-ICT intensive sectors]}

32. In countries behind the technological frontier the increases in productivity growth from product market reform are relatively large and persistent, implying large total benefits from reform. Because the productivity dividend is higher in these countries, the simulations suggest that convergence in productivity 
levels would have continued after 1995 if countries had aligned regulation in non-manufacturing sectors on that of the least restrictive OECD country (Figure 12).

\section{[Figure 12: The standard deviation of labour productivity across countries: actual and in a reform scenario]}

\section{Potential transmission channels}

33. The results of the previous section indicate that anti-competitive product market regulation has a statistically and economically significant negative effect on the speed with which countries operating behind the world productivity frontier catch up to best practice. This section investigates this link further by assessing the impact of product market regulation on two potential transmission channels that have been shown in previous work to influence the adoption of best practice production techniques. Specifically, regression analysis is used to test the effect of product market regulation on investment in ICT and the location decisions of multinational enterprises.

34. These two channels are most probably interrelated. For example, ICT-related industries tend to attract a disproportionate share of multinational enterprises. However, data constraints preclude estimating a generalised model that accounts for both channels simultaneously and the impact of regulation on each is analysed separately. In both cases the same panel data regression framework is used. Specifically, the following regression is estimated separately for each potential transmission channel:

$$
Y_{i j t}=R_{i j t} \alpha+X_{i j t} \beta+\gamma_{i}+\tau_{t}+\delta_{j}+\zeta_{i j t}+\varepsilon_{i j t} \quad \text { with } \quad \varepsilon \sim N(0, \Sigma)
$$

The variable Y represents one of the variables of interest - the ICT investment share or the employment share of foreign affiliates - at time $t$ in sector $j$ of country $i$. $R$ is a matrix of the appropriate regulatory indicators, $X$ is a matrix of controls that vary across each of the two regressions, and $\gamma, \tau$ and $\delta$ are country, time, and sector-specific fixed effects, which control for unobserved individual heterogeneity. The results for each of the two regressions are discussed in turn.

\subsection{The effect of product market regulation on ICT investment}

35. Given its potential for enhancing productivity and rapid price declines over recent years especially when adjusted for quality - ICT has spread rapidly throughout the OECD. On average across countries for which data exist, the share of ICT investment in total non-residential investment (measured at current prices) has increased from just over $10 \%$ in 1985 to just under $20 \%$ in 2002 (Figure 13). ${ }^{15}$ However, rates of ICT adoption have varied considerably across countries. In 2002, the share of ICT investment was particularly high in the United States, Sweden, Finland, Australia, and the United Kingdom. In contrast, ICT investment in some continental European countries and Japan was substantially lower. Several reasons can be envisaged for these differences, ranging from industry specialisation and first-mover advantage to gaps in workers' skills. However, given the wide availability of ICT and the relative homogeneity of industry features in the OECD area, cross-country differences in ICT uptake provide a useful 'natural experiment' with which to test the effect of product market regulation on the adoption of new technology.

15. The share of ICT investment in total investment is typically used as a key indicator of ICT diffusion. There are, however, many other indicators that measure the pervasiveness (or otherwise) of ICT technology across countries (see, for example, OECD 2002a). Most of these different indicators are closely correlated and tend to indicate a similar pattern of ICT diffusion. 


\section{[Figure 13: The diffusion of information communication technology]}

36. At first glance, there does appear to be a link between the diffusion of ICT and the restrictiveness of product market regulation (Figure 14). There are a number of potential reasons why this might be the case. In a competitive environment with low barriers to entry the incentive to invest in ICT so as to increase productivity and retain market share may be stronger than in a more restrictive regulatory environment where incumbents are sheltered from competitive processes. Investment in ICT may help firms increase productivity by, for example, allowing them to expand their product range, customise their services, and respond better to client demands. ICT may also help reduce inefficiencies in the production process by, for example, reducing inventories. In addition, the costs of adjusting the capital stock and firm structure and reorganising the production process, all of which are necessary if new technology is to be successfully integrated, will tend to be lower in a competitive environment. Finally, as pointed out by Alesina et al, (2005) in the context of general-purpose fixed investment, a competitive environment puts downward pressure on the cost of ICT, thereby promoting its diffusion.

\section{[Figure 14: Product market regulation and the diffusion of information communication technology]}

37. The regression model outlined above is used to test the impact of anti-competitive product market regulation on the share of ICT investment in total private investment. ${ }^{16}$ Reflecting data limitations, regressions are performed at the level of the aggregate business sector for 18 countries over the period 1985-2003 and at the sectoral level over the period 1980-2001 for five countries for which data on industry-specific ICT investment exist. ${ }^{17}$ As in the productivity regressions, the summary time-series indicator of anti-competitive regulation in seven non-manufacturing sectors is used as a proxy for economy-wide regulation in the aggregate model whereas the 'regulation impact' indicators are used in the sectoral model.

38. The aggregate and sectoral regression results are given in Tables 2 and 3 respectively. A measure of human capital is included as a control variable in the aggregate model given that countries with a more educated work force are better placed to benefit from ICT. This variable is marginally significant when country time trends and fixed effects are included in the aggregate regression. Given that a number of ICTusing sectors are services, the share of service sectors in business sector value-added is also included in the aggregate model to control for any effect of economic structure. This variable is found to be highly significant. ${ }^{18}$

\section{[Table 2: Share of investment in information and communication technology and regulation]}

\section{[Table 3: Share of investment in information and communication technology and regulation: sectoral regressions]}

39. In both versions of the model, the coefficients of the indicators of product market regulation are negatively signed and significant at the $1 \%$ level, implying that restrictions to competition have a strong negative effect on ICT investment. It would seem that firms operating in a relatively liberal regulatory

16. The specification of this model is similar to that used in the work of Gust and Marquèz (2004).

17. The countries covered in the aggregate-level regression are: Australia, Austria, Belgium, Canada, Denmark, Finland, France, Germany, Greece, Italy, Ireland, Japan, Netherlands, Portugal, Spain, Sweden, the United Kingdom, and the United States. At the sectoral level, only France, Germany, the Netherlands, the United Kingdom and the United States are included in the regression.

18. The services share is in some sense endogenous to ICT investment. However, regression results for the effect of product market regulation on ICT investment are robust to the exclusion of this variable. 
environment are more inclined to incorporate ICT into the production process than firms operating in an environment in which product market regulation is more restrictive. The sectoral results presented in Table $3 \mathrm{~b}$ suggest that the negative effect of domestic regulation on ICT investment is concentrated in nonICT producing sectors. This may reflect the fact that ICT-producing industries are strongly exposed to foreign competition. Also, the development of ICT-producing industries often reflects factors that are unrelated to regulation, such as first-mover advantage or specialisation due to country-specific comparative advantages and/or agglomeration economies.

40. To assess the effect of product market regulation on ICT investment in more detail, a range of indicators that measure specific aspects of regulation or regulation in specific sectors are included in the aggregate and sectoral regressions. When the public ownership component of the regulatory indicators is stripped out and included separately its coefficient is negative but insignificant in the aggregate regression and significantly positive in the sectoral regression, implying that public ownership per se need not inhibit the adoption of ICT (Table 3a, last column). In fact, especially in network industries, publicly-controlled firms have in some cases been found to over-invest in new technologies. For example, private telecommunications companies have sometimes abandoned costly plans to expand digital or cable networks in the wake of privatisation. This may explain the positive coefficient on public ownership in the sectoral regression where network industries have a larger impact on average estimates (because regressions are unweighted).

41. An economy-wide regulatory environment that is unfriendly to competition and excessive administrative burdens on firms are also found to curb investment in ICT (Table 2b). As well, there is some evidence that financing difficulties due to inappropriate banking regulation may also partially explain cross-country differences in ICT take-up (Table 3b). Finally, in both the aggregate and sectoral regressions, regulation in the retail trade sector is found to have a distinct negative impact on ICT investment.

42. According to these results, product market regulation is a statistically significant determinant of investment in ICT. But to what extent does it contribute to explain observed differences in ICT investment across countries? To answer this question Figure 15 graphs the contribution of each of the explanatory variables in the aggregate regression to deviations of ICT investment from the OECD average over the full sample period. Overall, product market regulation is estimated to explain $12 \%$ of the cross-country differences in ICT investment. In the United States, the share of ICT investment in total investment is found to be more than four percentage points higher than the OECD average of $15 \%$ as a result of relatively pro-competitive regulations. In the United Kingdom, Canada, and Australia, the estimated contribution of product market policies to investment in ICT relative to the OECD average also appears to have been significant (between 2.5 and 3.5 percentage points). Conversely, in Greece, Italy, Portugal and France relatively restrictive regulations are estimated to have significantly dragged down ICT investment relative to other OECD countries (by 2.5 to 3.5 percentage points).

\section{[Figure 15: Contributions to the deviation of the share of ICT in total investment from the OECD average, 1985-2003]}

43. Repeating the same exercise for 2003 suggests that the cross-country differences in ICT investment attributable to product market regulation are slightly smaller than over the full sample period, given a degree of regulatory convergence. However, both the overall picture and the country-specific results remain broadly unchanged. The contribution of policy is still noteworthy for some countries, implying that differences in the regulatory environment continue to explain a reasonable proportion of cross-country differences in ICT investment. Similar results are obtained using the sectoral version of the 
model, where the indicators of product market explain $20 \%$ of the variance in ICT investment across countries. ${ }^{19}$

44. Finally, the results of model simulations suggest that substantial increases in ICT investment would occur in a number of countries if they were to reform product market regulation to that of the least restrictive OECD country in each sector (Figure 16).

[Figure 16: Increase in ICT investment share following a move to economy-wide product market regulation that is least restrictive of competition]

\subsection{The effect of product market regulation on the location decisions of foreign affiliates}

45. The establishment of foreign affiliates in a host country is generally considered to be beneficial for domestic productivity growth. Previous empirical work has typically shown that foreign affiliates tend to be more capital and skill intensive and invest more in research and development than domestic firms in the same industry (Keller, 2004; Keller and Yeaple, 2003). As a result, foreign affiliates tend to grow more quickly and make a larger direct contribution to productivity growth in comparison to domestic firms (Criscuolo 2005). Foreign affiliates may also contribute indirectly to domestic productivity growth by generating positive productivity spillovers for local firms. For example, foreign affiliates may speed the diffusion of new technology and management practices across borders or train labour that is subsequently employed by local firms. Across the countries for which data are available, there is substantial variation in the share of foreign affiliates in total employment (Figure 17). ${ }^{20}$

\section{[Figure 17: Employment share of foreign affiliates in manufacturing sectors]}

46. As shown in Nicoletti et al. (2003), regulatory policies that restrict market access or reduce the potential returns to foreign investment negatively influence the share of foreign direct investment in OECD countries. At first glance, the employment share of foreign affiliates in the manufacturing sector indeed tends to be higher in countries with relatively liberal product market environments (Figure 18).

\section{[Figure 18: Product market regulation and the employment share of foreign affiliates in manufacturing, 1995-2003]}

47. As with the share of ICT investment, the same regression framework is used to test the effect of product market regulation on the location decisions of foreign affiliates. The share of employment by foreign affiliates in total employment at the sectoral level is regressed on the regulation impact indicators and a number of control variables. Specifically, the OECD indicators of FDI restrictions (Golub, 2003), sectoral tariff rates, measures of domestic absorption, human capital, growth in sectoral value added, and $R \& D$ intensity are also included in the regression. Tariff rates are included in the model given that the establishment of foreign affiliates may be a way to overcome trade barriers (so-called "tariff jumping"). Domestic absorption accounts for the size of the market accessed by foreign affiliates, and growth in

19 These additional results are available from the authors upon request.

20. The data on foreign affiliates are from Criscuolo (2005). The share of foreign affiliate employment in total employment is the preferred measure of the presence of foreign affiliates given a lack of cross-country comparability and gaps in the data for other measures. However, in services sectors these data are typically only available for more recent years and are more sparse than data for manufacturing. Accordingly, the sample is somewhat biased towards the manufacturing sector. Given data limitations, cross-country comparisons should be interpreted with caution. 
sectoral value added reflects the market potential in each sector. ${ }^{21} \mathrm{R} \& \mathrm{D}$ intensity captures the degree of innovation intrinsic in each industry. The indicator of regulation impact used in the regression is net of public ownership given that public ownership is included as part of the indicators of FDI restrictions. The model also includes industry-country fixed effects to account for other unobservable characteristics that might influence foreign affiliate employment. A dummy variable for membership in the European Union was also included in the model to reflect the effect of the larger market accessible to foreign affiliates in EU countries. Regressions were performed for 11 manufacturing and 7 service sectors in 14 countries from the early 1990 s to 2002 .

48. Regression results are presented in Table 4. Neither domestic absorption nor the proxy for market potential turn out to be significant, but membership in the European Union has a significant and positive effect on the share of employment in foreign affiliates, suggesting that the absence of border barriers and access to a continental market are factors that influence the location decisions of multinationals. Among the other controls, R\&D intensity is found to have a positive and significant effect, indicating that foreign affiliates tend to be attracted by relatively innovative sectors. Somewhat surprisingly, human capital has a significant negative influence on the establishment of foreign affiliates perhaps reflecting the effect of wage costs, which tend to increase with human capital. However, including various proxies for labour costs in the regression yields insignificant coefficients, while leaving the size and significance of the human capital variable unchanged.

\section{[Table 4: Regulation and the share of employment in foreign affiliates]}

49. Turning to policies, sectoral tariff barriers are estimated to have a positive effect on the employment share of foreign affiliates, suggesting some kind of "tariff-jumping" motive on behalf of multinational enterprises $>$ More importantly, regulatory restrictions to domestic competition and FDI are both found to have a significant negative effect on the employment share of foreign affiliates across model specifications. These results support the conjecture that, by raising barriers to entry, anti-competitive product market regulation discourages the establishment of foreign affiliates and their propensity to increase employment. ${ }^{22}$ Regression estimates imply that product market regulation explains around $10 \%$ of the cross-country variation in the data (Figure 19). Direct restrictions on FDI account for a further 13\%. Thus, altogether, regulatory settings have a relatively large impact on the cross-country variability of foreign affiliates' employment shares, especially in countries that combine relatively anticompetitive nonmanufacturing regulations with several FDI restrictions (e.g., Austria and Portugal). In this context, aligning sectoral product market policies and FDI restrictions on those of the least restrictive OECD country is estimated to substantially increase investment by multinationals in a number of countries (Figure 20). For instance, according to these estimates, such a move would roughly double the foreign affiliates' employment share in France, Germany, Belgium, Spain and Portugal, and would more than triple it in Austria, Japan, Italy and the United States.

\section{[Figure 19: Contributions to the deviation of the employment share of foreign affiliates from the} OECD average, 1995-2003]

21. The role of market potential, first introduced by Harris (1954), has recently been stressed in the context of FDI by Head and Mayer (2004).

22. The separate effect of product market regulation on the share of foreign affiliate employment in ICT intensive and non-ICT intensive sectors was also checked suggesting that the negative effect of anticompetitive regulation is larger and more significant in non-ICT intensive sectors. However, given the sparseness of data coverage, especially in services, this result needs to be interpreted with caution and is not reported here. 
[Figure 20: Increase in the employment share of foreign affiliates following a move to sectoral regulations and FDI restrictions that are least restrictive of competition]

\section{Directions for future research}

50. This paper has explored the effects of anticompetitive product market regulations on productivity growth and on two of its determinants, investment in ICT and spillovers from affiliates of foreign multinationals. The empirical results suggest that these effects can be substantial and could help explain the twin development of slowly converging product market policies and diverging productivities observed over the past two decades in the OECD area. There are several ways in which these results could be refined, extended and made more robust. First, the insights of recent developments in endogenous growth theory could be exploited more fully. For instance, so-called neo-Schumpeterian theories of growth suggest that the effects of competition policies could depend on several factors, including their precise nature (e.g. ease of access for new firms versus incentives for rivalry among incumbent firms) and the distance of countries or sectors from the technological frontier. This would suggest further investigation of the effects of various kinds of policies for which time-series indicators are available as well as further disaggregation that distinguishes different sectors and countries depending on their technological characteristics and level of development. Second, by looking at productivity and ICT separately, the analysis provides an incomplete account of the indirect effects that regulations may have on productivity through lower investment in ICT. The effects of regulation would presumably be better identified in a framework where the productivity and ICT models were estimated jointly. This, however, would require to specify a model of how ICT affects productivity. Third, product market regulations are just one set of institutions that may affect productivity developments. Future research could look at a wider set, including labour and financial market arrangements and education policies. 
ECO/WKP(2006)37

\section{ANNEX \\ DATA DESCRIPTION}

\section{Labour Productivity Data}

51. The aggregate data on business sector labour productivity are derived from national accounts and are calculated as the ratio of GDP to total employment in the business sector. GDP in the business sector in calculated by subtracting the value added of the government sector from total GDP, while employment in the business sector is the difference between total employment and employment in the government sector. GDP figures are made comparable across countries and over time by converting nominal values to 2000 purchasing power parities.

52. Sectoral labour productivity measures are derived from the data contained in the OECD STAN database for industrial analysis. Labour productivity is calculated as the ratio of sectoral value added to sectoral employment. As discussed in the text, aggregate purchasing power parities were used to make the sectoral productivity data comparable across sectors, countries and time. As for the aggregate measures, the base year chosen for the conversion of value-added is 2000 .

\section{ICT Data}

53. The aggregate ICT dataset used in this analysis consists of OECD data on gross fixed capital formation for eighteen countries over 1985-2001, with data for some countries through to 2003. The countries are Australia, Austria, Belgium, Canada, Denmark, Finland, France, Germany, Greece, Ireland, Italy, Japan, Netherlands, Portugal, Spain, Sweden, United Kingdom, and United States. The variable used in regressions, ICT share of total investment, is calculated as investment in hardware, software, and computer equipment divided by total investment.

54. The sectoral ICT data are obtained from the University of Groningen and are described in detail in Inklaar, O'Mahoney, and Timmer (2003). These data cover five countries France, Germany, Netherlands, United Kingdom, and United States, over 1980-2001, and are disaggregated to the two digit ISIC Rev.3 level.

\section{Foreign Affiliates Data}

55. The data used for the construction of variables concerning the activity of foreign affiliates are derived from three OECD databases: the STAN productivity database; the AFA database, which contains information on activity of foreign affiliates in the manufacturing sector and the FATS database, which contains information on activity of foreign affiliates in the service sector. Both the Activity of Foreign Affiliates (AFA) and the Foreign Affiliates in Trade and Services (FATS) are survey based data collected by the OECD Directorate for Science, Technology and Industry. Survey questions include employment, output, input and importing/exporting activity of foreign affiliates at the sectoral level. The countries covered in the analysis are Austria, Belgium, Finland, France, Germany, Italy, Japan, Netherlands, Norway, Portugal, Spain, Sweden, United Kingdom, United States, over the period 1977-2002, although coverage is most extensive in the 1990s.

56. Some issues arise with foreign affiliates' data. Firstly, STAN, which is used for the construction of sector totals, is based on national accounts, and therefore on several sources, establishment data being the most important. Reported information on the activity of foreign affiliates in AFA and FATS, on the other hand, is at the enterprise rather than the establishment level. This implies that the statistics concerning foreign affiliates might incorporate secondary activity and may not, therefore, be fully comparable with the sectoral totals derived from STAN. Secondly, the definition of foreign direct 
investment in both databases on the activity of foreign affiliates is based on the concept of controlling interest, which differs across countries. Thirdly, the definition of foreign owned firms within countries might have changed over time. Finally, statistics on foreign presence in some sectors are only provided for recent years.

57. Three possible measures of the presence of foreign affiliates are available: the share of turnover, the share of value-added, and the share of employment. The latter is the preferred measure of the presence of foreign affiliates given lack of cross-country comparability and gaps in the data for other measures.

\section{Data for other control variables}

58. The output gap is calculated as the difference between actual and potential output, based on national accounts and on the OECD Economic Outlook database. Aggregate human capital is calculated as the average years of education. As in Scarpetta and Tressel (2002), sectoral human capital is based on skill and wage data. It is calculated as the log of the wage ratios of high-skill to low-skill blue-collar and white-collar workers, weighted by the proportion of skilled workers in total employment. A measure of sectoral border barriers was calculated as a simple average of sectoral tariff and non-tariff barriers (from the UNCTAD/WB TRAINS database) and FDI restrictions (Golub, 2003). Data on R\&D expenditures are derived from the OECD ANBERD database.

\section{The classification of ICT-producing, ICT-using, and non-ICT intensive sectors}

59. Empirical measures of ICT use by sector are available for several countries, based on capital flow matrices and capital stock estimates. Work using data for the United States implies that investment in ICT equipment is concentrated in service sectors. For example, according to some estimates $78 \%$ of total business investment in ICT in the United States is undertaken in the wholesale and retail trade, finance, insurance, and real estate sectors. Manufacturing, on the other hand is found to be responsible for only $17 \%$ of ICT investment. The classification of ISIC rev.3 sectors into ICT-producing (P), ICT-using (U), and non-ICT intensive (N) sectors used in this paper follows Inklaar, et al., (2003) and is as follows:

\begin{tabular}{llc} 
ISIC code & \multicolumn{1}{c}{ Industry } & ICT classification \\
\hline $15-16$ & Food Products, beverages and tobacco & $\mathrm{N}$ \\
$17-19$ & Textiles, textiles products, leather \& footwear & $\mathrm{N}$ \\
20 & Wood except furniture & $\mathrm{N}$ \\
$21-22$ & Pulp, Paper, paper products, printing \& publishing & $\mathrm{U}$ \\
$23-25$ & Chemical, rubber, plastics \& fuel products & $\mathrm{N}$ \\
26 & Other non-metallic mineral products & $\mathrm{N}$ \\
$27-28$ & Basic metals and fabricated metal products & $\mathrm{N}$ \\
29 & Machinery and equipment, n.e.c. & $\mathrm{U}$ \\
$30-33$ & Electrical and optical equipment & $\mathrm{P}$ \\
$34-35$ & Transport equipment & $\mathrm{N}$ \\
$36-37$ & Furniture; recycling & $\mathrm{U}$ \\
$40-41$ & Electricity, gas and water supply & $\mathrm{N}$ \\
45 & Construction & $\mathrm{N}$ \\
$50-52$ & Wholesale and retail trade; repairs & $\mathrm{U}$ \\
55 & Hotels and restaurants & $\mathrm{N}$ \\
$60-63$ & Transport and storage & $\mathrm{N}$ \\
64 & Post and telecommunications & $\mathrm{P}$ \\
$65-67$ & Financial intermediation & $\mathrm{U}$ \\
70 & Real estate & $\mathrm{N}$ \\
$71-74$ & Renting of M\&EQ and other business activities & $\mathrm{U}$
\end{tabular}




\section{REFERENCES}

Acemoglu, D., P. Aghion and F. Zilibotti (2004), "Distance to Frontier, Selection, and Economic Growth", forthcoming, Journal of the European Economic Association

Aghion, P. and R. Griffith (2005), "Competition and Growth. Reconciling Theory and Evidence”, The MIT Press, Cambridge MA.

Aghion, P. and P. Howitt (2005), “Appropriate Growth Policy: A Unifying Framework”, 2005 Joseph Schumpeter Lecture, $20^{\text {th }}$ Annual Congress of the European Economic Association, Amsterdam, August 25.

Alesina, A., S. Ardagna, G. Nicoletti, and F. Schiantarelli (2005) "Regulation and Investment", Journal of the European Economic Association, Vol.3, No.4, 791-825.

Conway, P., V. Janod and G. Nicoletti (2005) "Product Market Regulation in OECD Countries: 1998 to 2003", OECD Economics Department Working Papers No.419.

Conway, P. and G. Nicoletti (2006), "Product Market Regulation in the Non-Manufacturing Sectors of OECD countries: Measurement and Highlights", OECD Economics Department Working Papers. Forthcoming.

Conway, P., D. De Rosa and G. Nicoletti (2006) "Competition and Productivity Convergence in the Age of ICT: Evidence from OECD Countries”, OECD Economics Department Working Papers, Forthcoming.

Criscuolo, C. (2005), "The Contribution of Foreign Affiliates to Productivity Growth: Evidence from OECD Countries", OECD STI Working Paper 2005/8.

Golub, S. (2003) "Measures of Restrictions on Inward Foreign Direct Investment for OECD Countries", OECD Economic Studies, No.36/1.

Griffith, R., S. Redding and J. Van Reenen (2004), "Mapping the Two Faces of R\&D: Productivity Growth in a Panel of OECD Countries", The Review of Economics and Statistics, November, 86(4), pp.883895.

Gust, C., and J. Marquez (2004), "International Comparisons of Productivity Growth: The Role of Information Technology and Regulatory Practices", Labour Economics, vol. 11, pp. 33-58.Harris, C. (1954), "The Market as a Factor in the Localization of Industry in the United States", Annals of the Association of American Geographers, 64, 315-348.

Head, K. and T. Mayer (2004), "Market Potential and the Location of Japanese Investment in the European Union", The Review of Economics and Statistics, 86(4), 959-972.

Inklaar, R., M. O’Mahony and M. Timmer (2003), "ICT and Europe's Productivity Performance: IndustryLevel Growth Account Comparisons with the United States", Groningen Growth and Development Centre, Research Memorandum GD-68.

Keller, W. (2004), “International Technology Diffusion”, Journal of Economic Literature, Volume XLII (September 2004), pp.752 - 782. 
Keller, W. and S. Yeaple (2003), "Multinational Enterprises, International Trade, and Productivity Growth: Firm Level Evidence from the United States", IMF Working Papers 248.

Nicoletti, G., S. Scarpetta and O. Boylaud (1999), "Summary Indicators of Product Market Regulation with an Extension to Employment Protection Legislation", OECD Economics Department Working Papers, $\mathrm{N}^{\mathrm{0}} 226$.

Nicoletti, G., S. Golub, D. Hajkova, D. Mirza and K.-Y. Yoo (2003), "The Influence of Policies on Trade and Foreign Direct Investment", OECD Economic Studies No.36

Nicoletti, G. and S. Scarpetta (2003), "Regulation, Productivity and Growth: OECD Evidence", Volume 18, Issue 36 (April).

OECD (2002a), "Measuring the Information Economy 2002”, www.oecd.org/sti/measuring-infoeconomy

OECD (2003a), “The Sources of Economic Growth in OECD Countries”, OECD, Paris.

OECD (2003b), "ICT and Economic Growth: Evidence from OECD countries, Industries and Firms", OECD, Paris.

Pilat, D. and A. Wölfl (2004), "ICT Production and ICT Use: What Role in Aggregate Productivity Growth?", in The Economic Impact of ICT: Measurement, Evidence and Implications. OECD, Paris.

Scarpetta S. and T. Tressel (2002), "Productivity and convergence in a panel of OECD industries: do regulations and institutions matter?", OECD Economics Department Working Papers, No. 329.

Van Ark, B., R. Inklaar and R. McGuckin (2002), “"Changing Gear” Productivity, ICT and Services: Europe and United States", Groningen Growth and Development Centre, Research Memorandum GD-60.

Van Biesebroeck (2004), "Cross-country Conversion Factors for Sectoral Productivity Comparisons", NBER Working Paper No.10279. 


\section{TABLES AND FIGURES}

\section{Tables}

1. Results of productivity growth regressions

2. Share of investment in information and communication technology and regulation

3. Share of investment in information and communication technology and regulation: sectoral regressions

4. Regulation and share of employment in foreign affiliates

\section{Figures}

1. Evolution and dispersion in regulatory environments, 1980-2003

2. The impact of regulation in ICT-producing, ICT-using, and non-ICT intensive sectors, 2003

3. Growth in business sector labour productivity per employee

4. The standard deviation of labour productivity across countries

5. $\quad$ Change in productivity levels relative to the United States

6. Contributions to aggregate labour productivity growth

7. Product market regulation and total economy labour productivity acceleration

8. The effect of regulation on the diffusion of a positive supply shock

9. Standard deviation of labour productivity across countries following a global supply shock: ICT and non-ICT intensive sectors

10. Increase in average annual business sector productivity growth over the period 1995 to 2003 given a move to sectoral regulations that are least restrictive of competition in 1995

11. Increase in average annual productivity growth over the period 1995 to 2003 given a move to sectoral regulations that are least restrictive of competition: ICT-intensive and non-ICT intensive sectors

12. The standard deviation of labour productivity across countries actual and in a reform scenario

13. The diffusion of information communication technology

14. Product market regulation and the diffusion of information communication technology

15. Contributions to the deviation of the share of ICT in total investment from the OECD average, 1985-2003

16. Increase in ICT investment share following a move to product market regulation that is least restrictive of competition

17. Employment share of foreign affiliates in the manufacturing sector

18. Product market regulation and the employment share of foreign affiliates in manufacturing, 19952003

19. Contributions to the deviation of the employment share of foreign affiliates from the OECD average, 1995-2003

20. Increase in the employment share of foreign affiliates following a move to sectoral regulations and FDI restrictions that are least restrictive of competition 
Table 1. Results of productivity growth regressions:

Panel A: Aggregate business sector ${ }^{1}$

Dependent Variable: Growth in labour productivity per employee

\begin{tabular}{|c|c|c|}
\hline Constant & $\begin{array}{c}-0.191 * * * \\
{[0.058]}\end{array}$ & $\begin{array}{c}-0.326 * * * \\
{[0.087]}\end{array}$ \\
\hline Change in productivity in the technology leader & $\begin{array}{c}0.249 * * * \\
{[0.075]}\end{array}$ & $\begin{array}{l}-0.126 \\
{[0.418]}\end{array}$ \\
\hline Gap in productivity levels (lagged 1 year) ${ }^{2}$ & $\begin{array}{c}-0.295 * * * \\
{[0.052]}\end{array}$ & $\begin{array}{c}-0.399 * * * \\
{[0.077]}\end{array}$ \\
\hline Product market regulation ${ }^{3}$ & $\begin{array}{c}0.002 \\
{[0.004]}\end{array}$ & $\begin{array}{c}0.005 \\
{[0.004]}\end{array}$ \\
\hline $\begin{array}{l}\text { Effect of regulation on catch up (interaction of regulation and productivity gap) } \\
\text { (lagged } 1 \text { year) }\end{array}$ & $\begin{array}{l}0.017 * * \\
{[0.009]}\end{array}$ & $\begin{array}{c}0.026 * * \\
{[0.011]}\end{array}$ \\
\hline Output Gap ${ }^{4}$ & $\begin{array}{l}0.092 * * \\
{[0.036]}\end{array}$ & $\begin{array}{l}0.097^{*} \\
{[0.051]}\end{array}$ \\
\hline 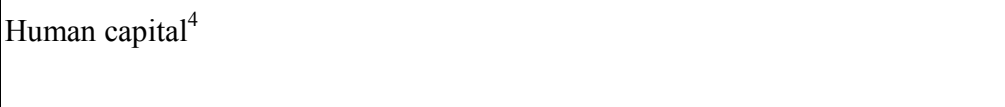 & $\begin{array}{l}0.012 * * \\
{[0.005]}\end{array}$ & $\begin{array}{c}0.023 * * * \\
{[0.009]}\end{array}$ \\
\hline ICT investment (as a share of total non-residential investment) ${ }^{4}$ & & $\begin{array}{l}0.131 * \\
{[0.069]}\end{array}$ \\
\hline Country fixed effects (jointly significant: F) & yes & yes \\
\hline Country time trends (jointly significant: F) & yes & yes \\
\hline Time dummies (jointly significant: F) & yes & yes \\
\hline $\begin{array}{l}\text { Observations } \\
\text { R-squared }\end{array}$ & $\begin{array}{l}518 \\
0.27\end{array}$ & $\begin{array}{c}288 \\
0.429\end{array}$ \\
\hline
\end{tabular}

Note: Robust SE in brackets. * significant at $10 \%$; ** significant at $5 \%$; *** significant at $1 \%$

1. The aggregate business sector model is estimated for 21 OECD countries over the period 1978 to 2003 .

2. Measured as the difference in the $(\log )$ level of productivity in each country relative to the productivity leader. The productivity leader is allowed to change over time.

3. Regulation is measured as the average of the indicators of regulation in seven non-manufacturing industries.

4. Data definitions are given in the Annex. 
ECO/WKP(2006)37

Table 1 (cont.) Results of productivity growth regressions:

Panel B: Sectoral ${ }^{1}$

Dependent Variable: Growth in labour productivity per employee

\begin{tabular}{|c|c|c|c|c|}
\hline Constant & $\begin{array}{c}-0.035^{* *} \\
{[0.016]}\end{array}$ & $\begin{array}{l}-0.066 \\
{[0.046]}\end{array}$ & $\begin{array}{c}-0.405^{* * *} \\
{[0.110]}\end{array}$ & $\begin{array}{l}-0.019 \\
{[0.025]}\end{array}$ \\
\hline Change in productivity in the technology leader & $\begin{array}{l}0.091^{* * *} \\
{[0.012]}\end{array}$ & $\begin{array}{c}0.104^{* * *} \\
{[0.014]}\end{array}$ & $\begin{array}{l}0.109^{* * *} \\
{[0.017]}\end{array}$ & $\begin{array}{c}0.106^{* * *} \\
{[0.015]}\end{array}$ \\
\hline Gap in productivity levels (lagged 1 year) ${ }^{2}$ & $\begin{array}{l}-0.097^{* * *} \\
{[0.007]}\end{array}$ & $\begin{array}{c}-0.126^{* * *} \\
{[0.011]}\end{array}$ & $\begin{array}{l}-0.096^{* * *} \\
{[0.010]}\end{array}$ & $\begin{array}{c}-0.093^{* * *} \\
{[0.008]}\end{array}$ \\
\hline Product market regulation ${ }^{3}$ & $\begin{array}{c}0.014 \\
{[0.020]}\end{array}$ & $\begin{array}{l}-0.016 \\
{[0.028]}\end{array}$ & $\begin{array}{l}0.012 \\
{[0.026]}\end{array}$ & \\
\hline Product market regulation ICT-intensive sectors ${ }^{3}$ & & & & $\begin{array}{c}-0.076^{* *} \\
{[0.038]}\end{array}$ \\
\hline Product market regulation non-ICT-intensive sectors ${ }^{3}$ & & & & $\begin{array}{c}0.004 \\
{[0.031]}\end{array}$ \\
\hline $\begin{array}{l}\text { Effect of regulation on catch up (interaction of regulation and productivity gap) } \\
\text { (lagged } 1 \text { year) }\end{array}$ & $\begin{array}{l}0.061^{* * *} \\
{[0.017]}\end{array}$ & $\begin{array}{l}0.097^{* * *} \\
{[0.030]}\end{array}$ & $\begin{array}{l}0.052^{* *} \\
{[0.024]}\end{array}$ & $\begin{array}{l}0.049^{* *} \\
{[0.022]}\end{array}$ \\
\hline Human capital $^{4}$ & & $\begin{array}{c}0.034 \\
{[0.034]}\end{array}$ & & \\
\hline Change in capital per worker ${ }^{4}$ & & & $\begin{array}{c}0.029^{* * *} \\
{[0.008]}\end{array}$ & \\
\hline Country-Industry fixed effects (jointly significant: F) & yes & yes & yes & yes \\
\hline Industry time trends (jointly significant: $\mathrm{F}$ ) & yes & yes & yes & yes \\
\hline Time dummies (jointly significant: F) & yes & yes & yes & yes \\
\hline $\begin{array}{l}\text { Observations } \\
\text { R-squared }\end{array}$ & $\begin{array}{l}6404 \\
0.301\end{array}$ & $\begin{array}{l}3742 \\
0.395\end{array}$ & $\begin{array}{l}4525 \\
0.208\end{array}$ & $\begin{array}{l}6439 \\
0.187\end{array}$ \\
\hline
\end{tabular}

Note: Robust SE in brackets. * significant at $10 \% ; * *$ significant at $5 \% ; * * *$ significant at $1 \%$

1. The sectoral model is estimated for 20 OECD countries over the period 1981 to 2003. It is estimated for 21 ISIC rev. 3 sectors

2. Measured as the difference in the $(\log )$ level of productivity in each country/sector relative to the productivity leader. The productivity leader is allowed to change over time and across sectors.

3. Regulation is measured using the regulation impact indicators described in Conway et al (2006).

4. Data definitions are given in the Annex. 
Table 2. Share of investment in information and communication technology and regulation

A: Baseline aggregate regressions: 18 Countries, 1985 - 2003

Dependent variable: ICT share in total investment

\begin{tabular}{|c|c|c|c|c|c|}
\hline \multirow[b]{2}{*}{ Constant } & \multirow{2}{*}{$\begin{array}{c}\text { OLS } \\
-0.072 \\
(0.045)\end{array}$} & \multicolumn{4}{|c|}{ Fixed Effects Random Effects Fixed Effects Fixed Effects } \\
\hline & & $\begin{array}{c}0.08 \\
(0.068)\end{array}$ & $\begin{array}{c}0.076 \\
(0.062)\end{array}$ & $\begin{array}{l}-0.168 \\
(0.119)\end{array}$ & $\begin{array}{c}-0.13 \\
(0.119)\end{array}$ \\
\hline Human capital & $\begin{array}{c}0.000 \\
(0.001)\end{array}$ & $\begin{array}{l}-0.001 \\
(0.005)\end{array}$ & $\begin{array}{c}0.001 \\
(0.004)\end{array}$ & $\begin{array}{c}0.021 * * \\
(0.01)\end{array}$ & $\begin{array}{l}0.018 * \\
(0.010)\end{array}$ \\
\hline Business services share & $\begin{array}{c}0.602 * * * \\
(0.076)\end{array}$ & $\begin{array}{c}0.384 * * * \\
(0.11)\end{array}$ & $\begin{array}{c}0.357 * * * \\
(0.097)\end{array}$ & $\begin{array}{c}0.45 * * * \\
(0.104)\end{array}$ & $\begin{array}{c}0.439 * * * \\
(0.102)\end{array}$ \\
\hline Regulation $^{1}$ & $\begin{array}{c}-0.012 * * * \\
(0.003)\end{array}$ & $\begin{array}{c}-0.021 * * * \\
(0.003)\end{array}$ & $\begin{array}{c}-0.021 * * * \\
(0.003)\end{array}$ & $\begin{array}{c}-0.021 * * * \\
(0.003)\end{array}$ & \\
\hline Regulation net of public ownership ${ }^{1}$ & & & & & $\begin{array}{c}-0.015 * * * \\
(0.003)\end{array}$ \\
\hline Public ownership ${ }^{1}$ & & & & & $\begin{array}{l}-0.006 \\
(0.004)\end{array}$ \\
\hline Country fixed effects (jointly significant: F) & no & yes & no & yes & yes \\
\hline Country time trends (jointly significant: F) & yes & no & no & yes & yes \\
\hline Test Ho: Homoskedasticity (chi2) & 1.97 & & & & \\
\hline Prob $>$ chi2 & 0.160 & & & & \\
\hline Breusch Pagan LM (chi 2) & & 1001.49 & & & \\
\hline Prob $>$ chi2 & & 0.000 & & & \\
\hline Hausman Test Fixed vs. Random Effects (chi2) & & 0.40 & & & \\
\hline Prob > chi2 & & 0.940 & & & \\
\hline Observations & 289 & 289 & 289 & 289 & 289 \\
\hline R-squared & $87 \%$ & $56 \%$ (within) & $56 \%$ (within) & $84 \%$ (within) & $85 \%$ (within) \\
\hline
\end{tabular}


Table 2 (cont.)

B. Random effects regressions including time-invariant indicators of regulation in additional service sectors Aggregate regressions: 18 Countries, 1985 - 2003

\begin{tabular}{|c|c|c|c|c|c|}
\hline Constant & $\begin{array}{l}-0.081 * \\
(0.045)\end{array}$ & $\begin{array}{l}-0.009 \\
(0.042)\end{array}$ & $\begin{array}{l}-0.09 * \\
(0.047)\end{array}$ & $\begin{array}{l}-0.036 \\
(0.046)\end{array}$ & $\begin{array}{c}-0.116^{* * *} \\
(0.036)\end{array}$ \\
\hline Human capital & $\begin{array}{c}0.000 \\
(0.001)\end{array}$ & $\begin{array}{c}-0.003 * * \\
(0.001)\end{array}$ & $\begin{array}{l}-0.001 \\
(0.001)\end{array}$ & $\begin{array}{l}-0.002 \\
(0.001)\end{array}$ & $\begin{array}{l}-0.003 \\
(0.002)\end{array}$ \\
\hline Business service share & $\begin{array}{c}0.664 * * * \\
(0.084)\end{array}$ & $\begin{array}{c}0.566^{* * *} \\
(0.069)\end{array}$ & $\begin{array}{c}0.635 * * * \\
(0.077)\end{array}$ & $\begin{array}{c}0.593 * * * \\
(0.074)\end{array}$ & $\begin{array}{c}0.784 * * * \\
(0.061)\end{array}$ \\
\hline Regulation $^{1}$ & $\begin{array}{c}-0.012 * * * \\
(0.003)\end{array}$ & $\begin{array}{c}-0.006 * * \\
(0.002)\end{array}$ & $\begin{array}{c}-0.009 * * * \\
(0.003)\end{array}$ & $\begin{array}{c}-0.009 * * * \\
(0.003)\end{array}$ & \\
\hline Banking regulation $(2003)^{2}$ & $\begin{array}{l}-0.021^{*} \\
(0.013)\end{array}$ & & & & \\
\hline Retail regulation $(1998)^{2}$ & & $\begin{array}{c}-0.017 * * * \\
(0.002)\end{array}$ & & & \\
\hline Professional services regulation $(1998)^{2}$ & & & $\begin{array}{c}0.001 \\
(0.003)\end{array}$ & & \\
\hline Administrative burdens (1998) $)^{3}$ & & & & $\begin{array}{c}-0.015^{* * *} \\
(0.005)\end{array}$ & \\
\hline Economy-wide regulation $(1998)^{3}$ & & & & & $\begin{array}{c}-0.035^{* * *} \\
(0.008)\end{array}$ \\
\hline Country time trends (jointly significant: F) & yes & yes & yes & yes & yes \\
\hline $\begin{array}{l}\text { Observations } \\
\text { R-squared }\end{array}$ & $\begin{array}{c}289 \\
67 \% \text { (within }\end{array}$ & $\begin{array}{c}272 \\
72 \% \text { (within) }\end{array}$ & $\begin{array}{c}256 \\
66 \% \text { (within) } \\
\end{array}$ & $\begin{array}{c}289 \\
68 \% \text { (within) }\end{array}$ & $\begin{array}{c}289 \\
67 \% \text { (within) } \\
\end{array}$ \\
\hline
\end{tabular}

Standard errors in parentheses; * significant at $10 \% ; * *$ significant at $5 \% ; * * *$ significant at $1 \%$

1. Summary time-series indicator of anticompetitive regulation in 7 non-manufacturing sectors.

2. Regulation data for individual service sectors that are available for only one or two periods.

The earliest available observation has been used as a regressor.

3. Regulation data in broad areas that are available for only one or two periods (See Conway et al ., 2005). 
ECO/WKP(2006)37

Table 3. Share of investment in information and communication technology and regulation: sectoral regressions

A. Baseline sectoral regressions

\begin{tabular}{|c|c|c|c|c|c|c|c|c|}
\hline & OLS & Robust & $\begin{array}{c}\text { Random } \\
\text { effects }\end{array}$ & Fixed effects & Fixed effects & $\begin{array}{l}\text { Robust fixed } \\
\text { effects }\end{array}$ & $\begin{array}{l}\text { Robust fixed } \\
\text { effects }\end{array}$ & $\begin{array}{l}\text { Robust fixed } \\
\text { effects }\end{array}$ \\
\hline Constant & $\begin{array}{l}0.16^{* * *} \\
(0.008)\end{array}$ & $\begin{array}{l}0.16^{* * *} \\
(0.007)\end{array}$ & $\begin{array}{c}0.183^{* * *} \\
(0.009)\end{array}$ & $\begin{array}{l}0.15^{* * *} \\
(0.009)\end{array}$ & $\begin{array}{c}0.115^{* * *} \\
(0.008)\end{array}$ & $\begin{array}{c}0.084 * * * \\
(0.009)\end{array}$ & $\begin{array}{c}0.079 \\
(0.008)^{* * *}\end{array}$ & $\begin{array}{c}0.073^{* * *} \\
(0.007)\end{array}$ \\
\hline Regulation impact $^{2}$ & $\begin{array}{c}-0.141^{* * * *} \\
(0.011)\end{array}$ & $\begin{array}{c}-0.141^{* * *} \\
(0.010)\end{array}$ & $\begin{array}{c}-0.182 * * * \\
(0.011)\end{array}$ & $\begin{array}{c}-0.122 * * * \\
(0.012)\end{array}$ & $\begin{array}{c}-0.059^{* * *} \\
(0.011)\end{array}$ & $\begin{array}{c}-0.068^{* * *} \\
(0.012)\end{array}$ & $\begin{array}{c}-0.059^{* * *} \\
(0.011)\end{array}$ & \\
\hline Regulation impact net of public ownership $^{2}$ & & & & & & & & $\begin{array}{c}-0.124 * * * \\
(0.011)\end{array}$ \\
\hline Public ownership ${ }^{2}$ & & & & & & & & $\begin{array}{l}0.1 * * * \\
(0.014)\end{array}$ \\
\hline Industry trends (jointly significant: F) & Yes & Yes & No & No & Yes & Yes & Yes & Yes \\
\hline Industry dummies (jointly significant: F) & Yes & Yes & Yes & Yes & Yes & Yes & Yes & Yes \\
\hline Country dummies (jointly significant: $F$ ) & No & No & No & Yes & Yes & Yes & Yes & Yes \\
\hline Country trends (jointly significant: F) & No & No & No & No & No & No & Yes & No \\
\hline $\begin{array}{l}\text { Ho: Homoskedasticity (Chi2) } \\
\text { (Prob > Chi2) }\end{array}$ & $\begin{array}{c}385.62 \\
0.000\end{array}$ & & & & $\begin{array}{l}233.17 \\
'(0.000)\end{array}$ & & & \\
\hline $\begin{array}{l}\text { Breusch Pagan LM (Chi2) } \\
\text { (Prob > Chi2) }\end{array}$ & & & & $\begin{array}{l}7197.48 \\
(0.000)\end{array}$ & & & & \\
\hline $\begin{array}{l}\text { Hausman }(\text { Chi2) } \\
(\text { Prob }>\text { Chi2 })\end{array}$ & & & $\begin{array}{l}286.91 \\
(0.000)\end{array}$ & & & & & \\
\hline Observations & 1954 & 1954 & 1954 & 1954 & 1954 & 1954 & 1954 & 1954 \\
\hline R-squared & $73 \%$ & $73 \%$ & $68 \%$ (within) & $68 \%$ (within) & $77 \%$ (within) & $75 \%$ & $79 \%$ & $79 \%$ \\
\hline
\end{tabular}

Standard errors in parentheses. * *ignificant at $10 \% ; *$ s significant at $5 \% ; * *$ significant at $1 \%$

2. See Conway and Nicoletti (2006) for a description of regulation impact indicators.

Note: Human capital was omitted to avoid loss of degrees of freedom and due to insignificance. 
Table 3 (cont.)

B. Impact of regulation in particular sectors

\begin{tabular}{|c|c|c|}
\hline & $\begin{array}{c}\text { Robust fixed } \\
\text { effects }\end{array}$ & $\begin{array}{c}\text { Random } \\
\text { effects }\end{array}$ \\
\hline Constant & $0.122 * * *$ & $0.17 * * *$ \\
\hline Regulation impact ICT-using ${ }^{2}$ & $\begin{array}{c}(0.009) \\
-0.07 * * *\end{array}$ & \\
\hline & $(0.012)$ & \\
\hline Regulation impact ICT-producing ${ }^{2}$ & $\begin{array}{l}-0.121 \\
(0.082)\end{array}$ & \\
\hline Regulation impact non- ICT $^{2}$ & $\begin{array}{c}-0.097 * * * \\
(0.013)\end{array}$ & \\
\hline Regulation impact net of regulation in retail distribution ${ }^{2}$ & & $\begin{array}{c}-0.064 * * * \\
(0.012)\end{array}$ \\
\hline Regulation in retail distribution $(1998)^{3}$ & & $\begin{array}{c}-0.017 * * * \\
(0.001)\end{array}$ \\
\hline Industry trends (jointly significant: F) & Yes & Yes \\
\hline Industry dummies (jointly significant: F) & Yes & Yes \\
\hline Country dummies (jointly significant: F) & Yes & No \\
\hline $\begin{array}{l}\text { Test Ho: Regulation impact differs: ICT using vs. } \\
\text { producing vs. non-ICT (F) }\end{array}$ & 2.30 & \\
\hline$(\operatorname{Prob}>$ F $)$ & 0.100 & \\
\hline $\begin{array}{l}\text { Hausman }(\text { Chi2) } \\
(\text { Prob }>\text { Chi2) }\end{array}$ & & $\begin{array}{c}28.64 \\
(0.8036)\end{array}$ \\
\hline Observations & 1954 & 1570 \\
\hline R-squared & $78 \%$ (within) & $76 \%$ (within) \\
\hline
\end{tabular}

Robust standard errors in parentheses. * significant at $10 \%$; * significant at $5 \%$; ** significant at $1 \%$

1. Countries: France, Germany, Netherlands, United Kingdom, United States. Period: 1980 - 2001. 19 manufacturing and service sectors, see Annex for details.

2. See Conway and Nicoletti (2006) for a description of regulation impact indicators.

3. See Boylaud and Nicoletti (2001) 


\begin{tabular}{|c|c|c|c|c|c|c|}
\hline \multirow[b]{2}{*}{ Constant } & \multicolumn{2}{|l|}{ Fixed effects } & \multicolumn{3}{|c|}{ Robust Fixed Effects } & \multirow[b]{2}{*}{$\begin{array}{c}0.103 * * * \\
{[0.018]}\end{array}$} \\
\hline & $\begin{array}{c}0.192 \\
{[0.153]}\end{array}$ & $\begin{array}{c}0.192 \\
{[0.153]}\end{array}$ & $\begin{array}{c}0.587 * * * \\
{[0.046]}\end{array}$ & $\begin{array}{c}0.444 * * * \\
{[0.041]}\end{array}$ & $\begin{array}{c}0.299 * * * \\
{[0.043]}\end{array}$ & \\
\hline EU15 dummy & $\begin{array}{c}0.068 * * * \\
{[0.005]}\end{array}$ & $\begin{array}{c}0.068 * * * \\
{[0.005]}\end{array}$ & $\begin{array}{c}0.083 * * * \\
{[0.001]}\end{array}$ & $\begin{array}{c}0.071 * * * \\
{[0.006]}\end{array}$ & $\begin{array}{c}0.062 * * * \\
{[0.015]}\end{array}$ & $\begin{array}{c}0.043 * * * \\
{[0.009]}\end{array}$ \\
\hline Domestic absorption $(\mathrm{C}+\mathrm{I}+\mathrm{G})$ at $\mathrm{PPP}$ & & & $\begin{array}{c}0.000 \\
{[0.000]}\end{array}$ & & $\begin{array}{c}0.000 \\
{[0.000]}\end{array}$ & \\
\hline Sectoral human capital & & & $\begin{array}{c}-0.322 * * * \\
{[0.039]}\end{array}$ & & $\begin{array}{c}-0.489 * * * \\
{[0.055]}\end{array}$ & \\
\hline Sectoral VA growth & & & & & $\begin{array}{c}-0.024 \\
{[0.061]}\end{array}$ & \\
\hline Sectoral R\&D intensity: share of $R \& D$ in sectoral VA & & & & & $\begin{array}{c}0.787 * * * \\
{[0.250]}\end{array}$ & \\
\hline Regulation impact net of public ownership ${ }^{2}$ & $\begin{array}{c}-0.118 * * * \\
{[0.034]}\end{array}$ & $\begin{array}{c}-0.118 * * * \\
{[0.034]}\end{array}$ & $\begin{array}{c}-0.385 * * * \\
{[0.069]}\end{array}$ & $\begin{array}{c}-0.373 * * * \\
{[0.060]}\end{array}$ & $\begin{array}{c}-0.281 * * * \\
{[0.103]}\end{array}$ & $\begin{array}{c}-0.390 * * * \\
{[0.085]}\end{array}$ \\
\hline Sectoral FDI restrictions ${ }^{3}$ & $\begin{array}{c}-0.223 * * * \\
{[0.032]}\end{array}$ & $\begin{array}{c}-0.223 * * * \\
{[0.039]}\end{array}$ & $\begin{array}{c}-0.270 * * * \\
{[0.050]}\end{array}$ & $\begin{array}{c}-0.268 * * * \\
{[0.047]}\end{array}$ & $\begin{array}{c}-0.575 * * * \\
{[0.075]}\end{array}$ & $\begin{array}{c}-0.510 * * * \\
{[0.074]}\end{array}$ \\
\hline Sectoral tariff barriers ${ }^{3}$ & & & $\begin{array}{c}0.024 \\
{[0.023]}\end{array}$ & & $\begin{array}{l}0.078 * * \\
{[0.032]}\end{array}$ & \\
\hline Industry dummies (jointly significant: F) & Yes & Yes & Yes & Yes & Yes & Yes \\
\hline Industry specific trends (jointly significant: F) & Yes & Yes & Yes & Yes & Yes & Yes \\
\hline $\begin{array}{l}\text { Ho: Homoskedasticity (Chi2) } \\
\text { (Prob > Chi2) }\end{array}$ & $\begin{array}{c}321.32 \\
0.000\end{array}$ & & & & & \\
\hline Observations & 1331 & 1331 & 838 & 838 & 396 & 396 \\
\hline R-squared (within) & $51.3 \%$ & $51.3 \%$ & $63.1 \%$ & $60.4 \%$ & $72.4 \%$ & $64.5 \%$ \\
\hline
\end{tabular}

Standard errors in parentheses. ${ }^{*}$ significant at $10 \%$; ** significant at $5 \% ; * * *$ significant at $1 \%$

1. Countries: Austria, Belgium, Finland, France, Germany, Italy, Japan, Netherlands, Norway, Portugal, Spain, Sweden, United Kingdom, United States.

Period: 1997 - 2002. 11 manufacturing and 7 service sectors. See Annex 3 for details on data.

2. See box 2 and Annex 2 for a description of the regulation impact indicators.

3. Golub (2003). See Annex 2 for details. 
Figure 1. Evolution and dispersion in regulatory environments, $1980-2003^{1}$

The scale of the indicators is 0-6 from least to most restrictive

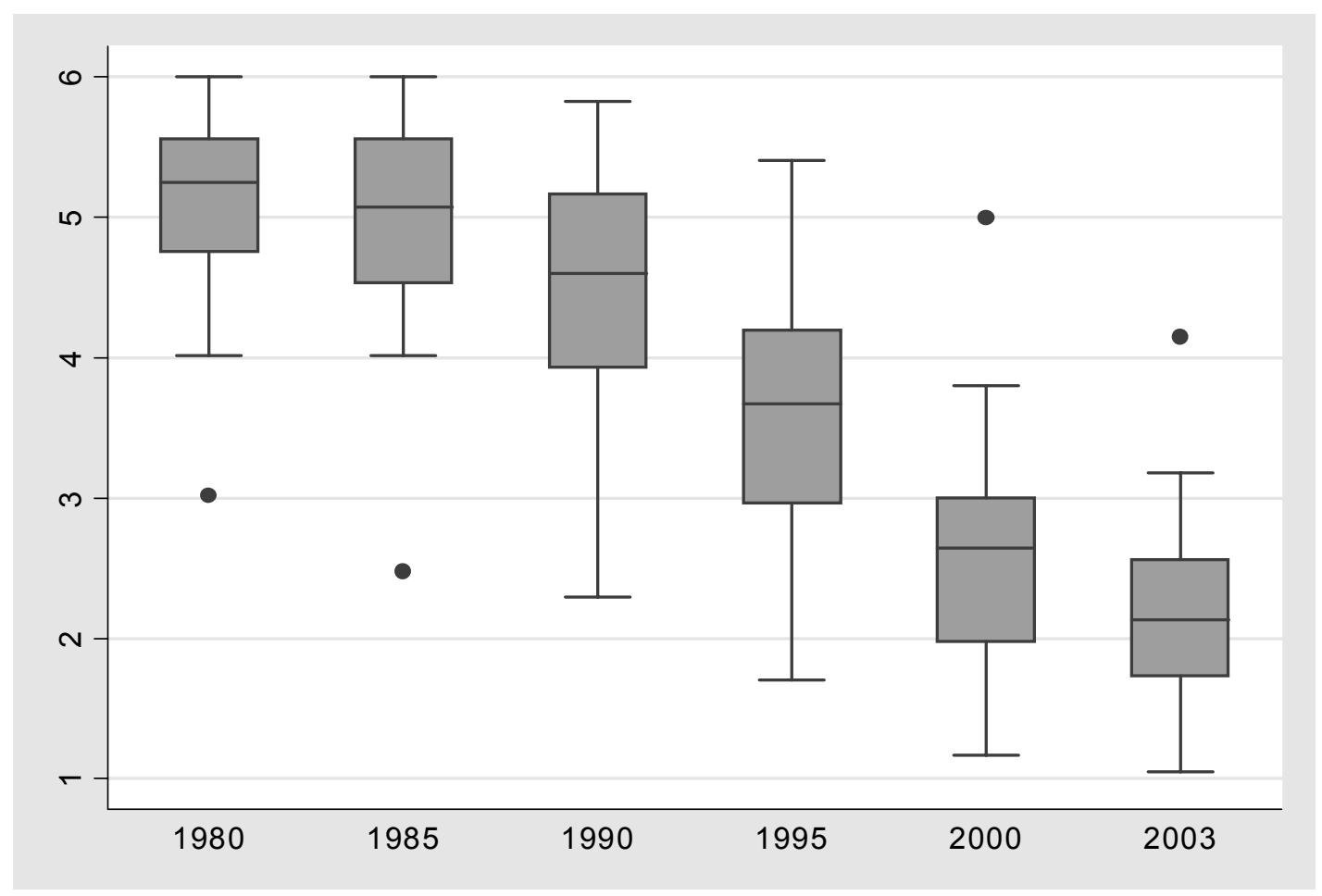

1. Box plot of the summary indicators of regulatory conditions in seven non-manufacturing sectors. The horizontal line in the middle of the box is the median value of the indicator across the 21 OECD countries for which these indicators exist. The edges of the box are the 2 nd and 3rd quartiles of the cross country distribution. The two whiskers are the extreme values and the dots represent outliers (the United States in 1980 and 1985 and Greece in 2000 and 2003).

Source: OECD international regulation database 
Figure 2. The impact of regulation in ICT-producing, ICT-using, and non-ICT intensive sectors, $2003{ }^{1}$ The scale of the indicators is $0-1$ from least to most restrictive

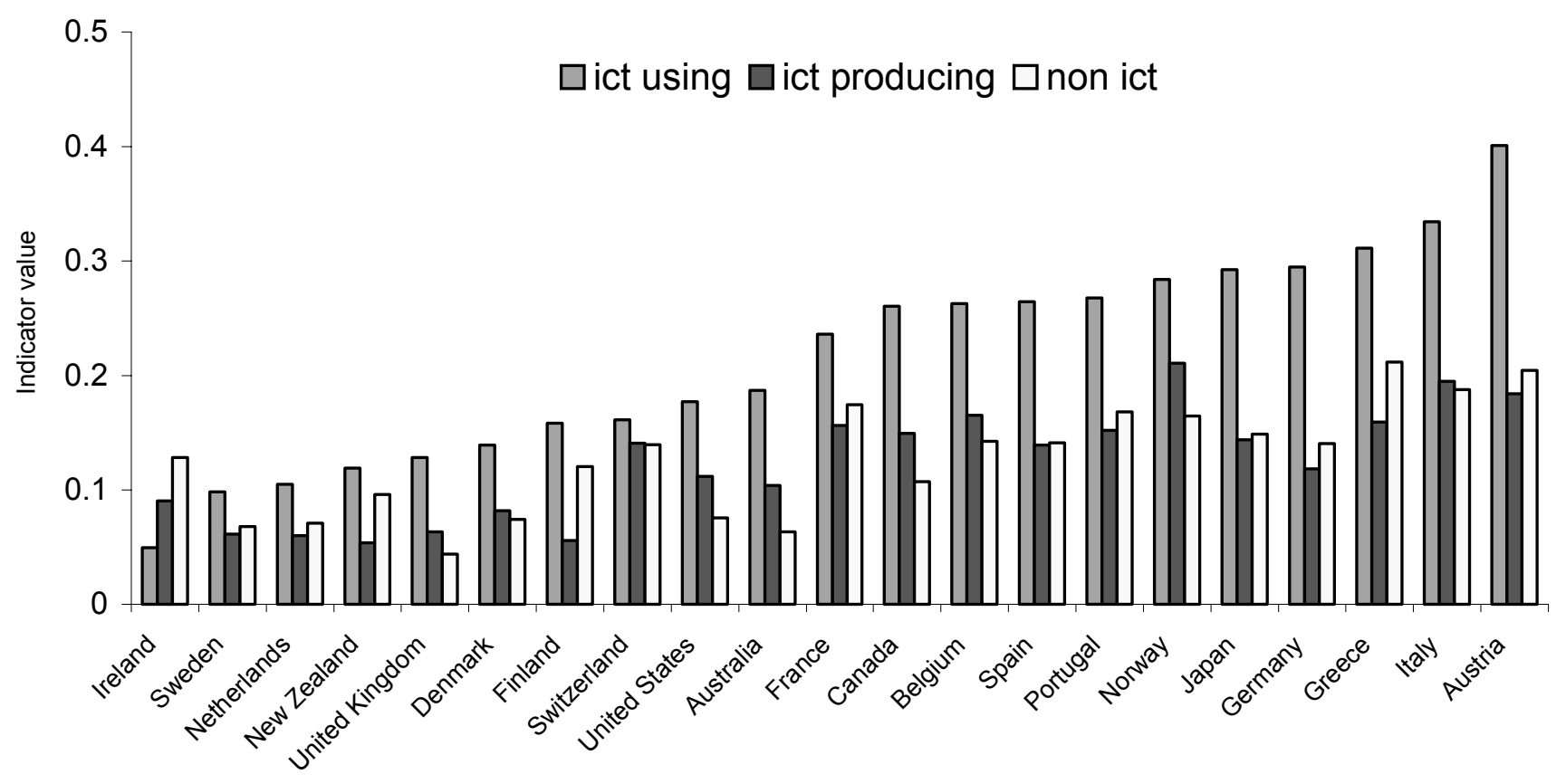

1 These data are the simple averages of the 'regulation impact' indicators for the individual industries included in ICT-producing, ICTusing, and non-ICT intensive sectors in 2003. The classification of sectors as ICT-using, ICT-producing, and non-ICT intensive is discussed in the data annex. The data is ordered according to the indicator values for ICT-using sectors.

Source: OECD international regulation database 
Figure 3. Growth in business sector labour productivity per employee ${ }^{1}$

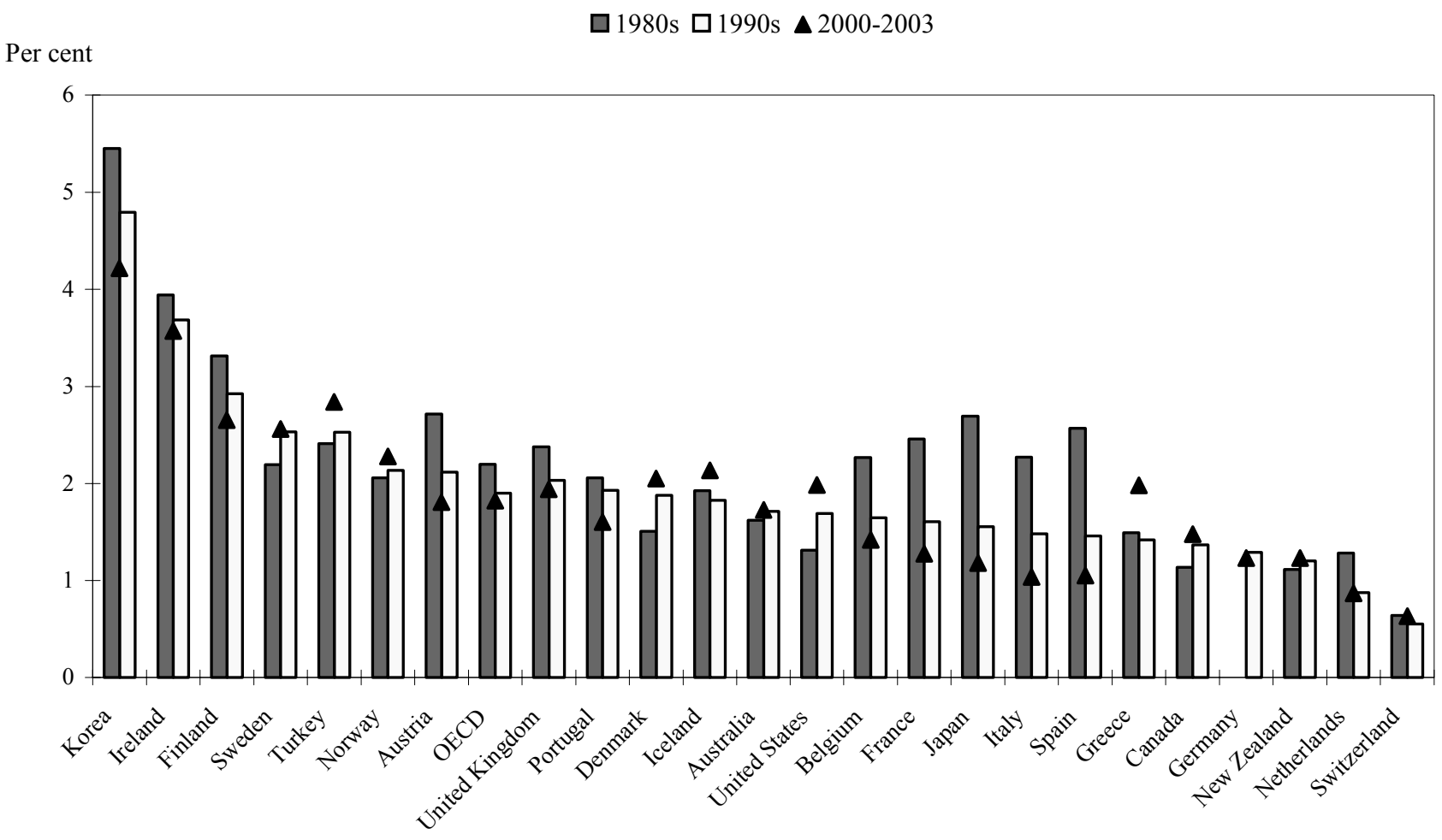

1 Average annual growth rates, based on cyclically-adjusted series of business sector output and employment (Hodrick-Prescott filter, lambda $=100$, data extended to 2006 using OECD medium-term projections to mitigate the end-point problem inherent with this filter). Countries are ordered according to productivity growth in the 1990s.

Source: OECD 
Figure 4. The standard deviation of labour productivity across countries ${ }^{1}$

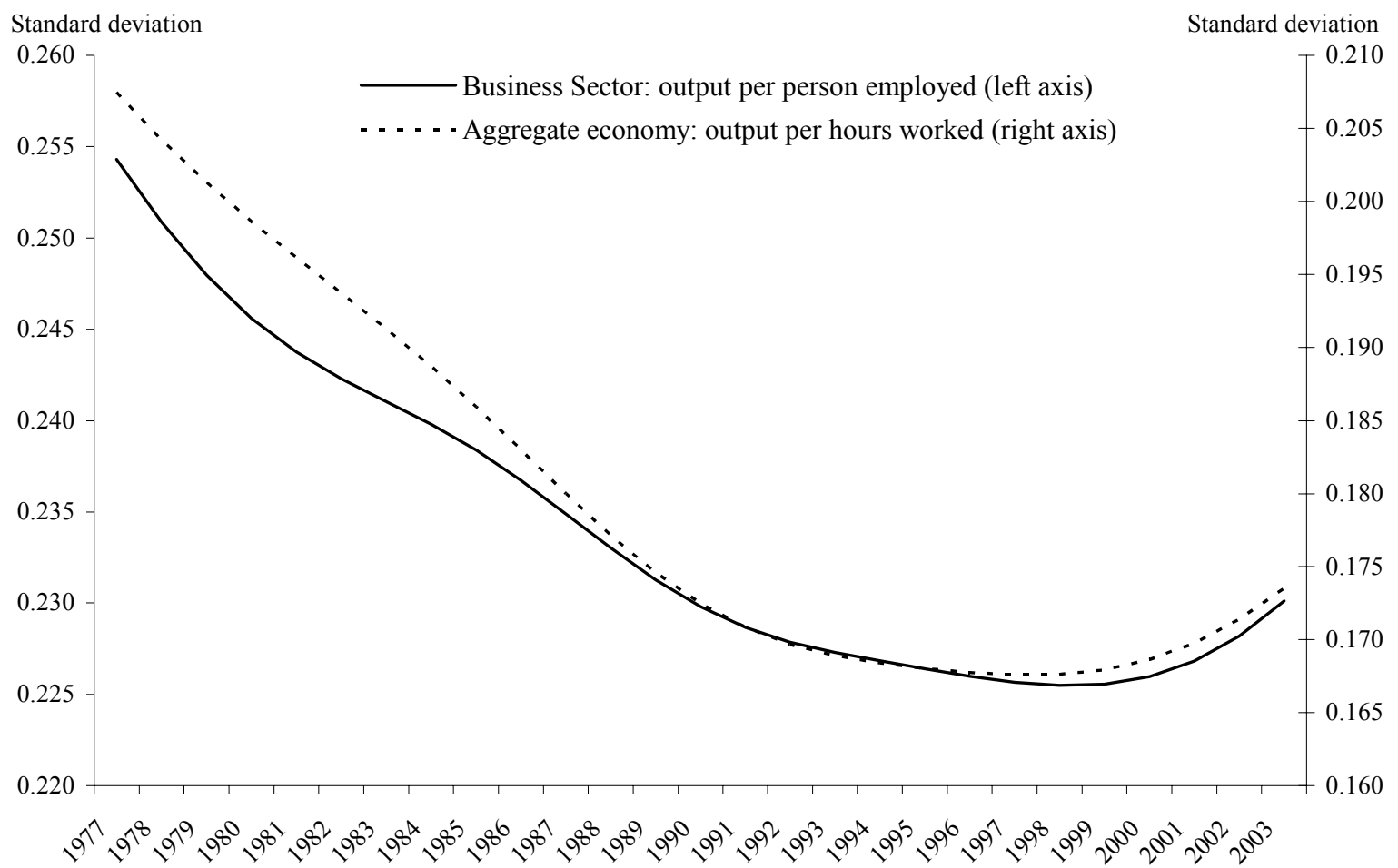

1 Calculated using cyclically-adjusted series of output and employment in the business sector for 21 OECD countries and output and hours worked for 18 OECD countries based on data availability (Hodrick-Prescott filter, lambda=100, data extended to 2006 using OECD medium-term projections to mitigate the end-point problem inherent with this filter).

Source: OECD 
Figure 5. Change in productivity levels relative to the United States ${ }^{1}$

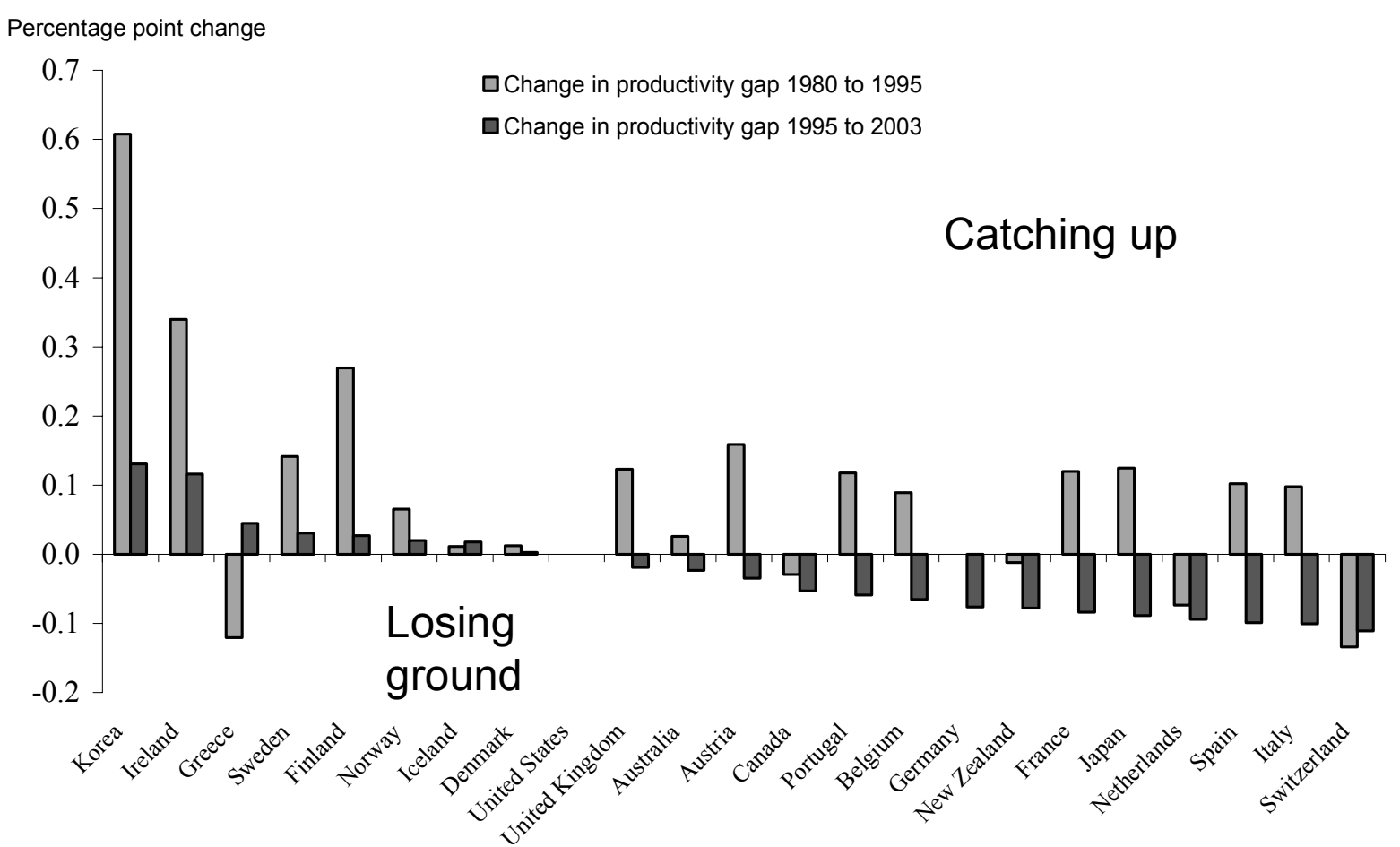

1 Based on cyclically-adjusted series of business sector output and employment (Hodrick-Prescott filter, lambda=100, data extended to 2006 using OECD medium-term projections to mitigate the end-point problem inherent with this filter). The productivity gap is the (log) difference between business sector labour productivity per employee in each country and the United States. Countries are ordered according to the change in the productivity gap in the most recent period.

Source: OECD 
Figure 6. Contributions to aggregate labour productivity growth ${ }^{1}$

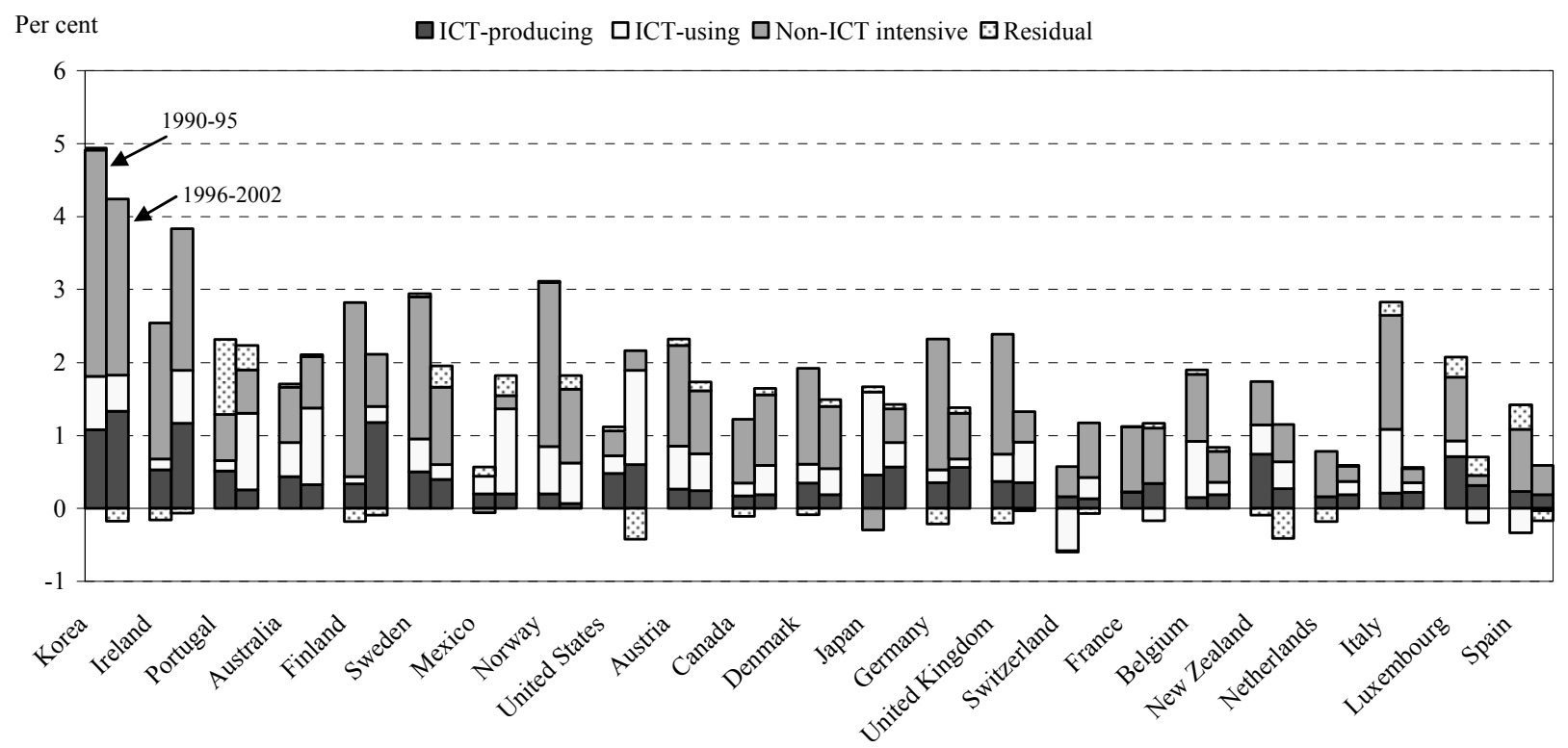

1 Annual average contributions to the growth of total value added per person employed, in percentage points. The residual reflects adding up differences in aggregating from sectoral to the aggregate economy level. Countries are ordered according to labour productivity growth in the most recent period.

Source: Pilat, Lee, van Ark (2002) (updated) 
Figure 7. Product market regulation and total economy labour productivity acceleration

The scale of the indicators is $0-6$ from least to most restrictive

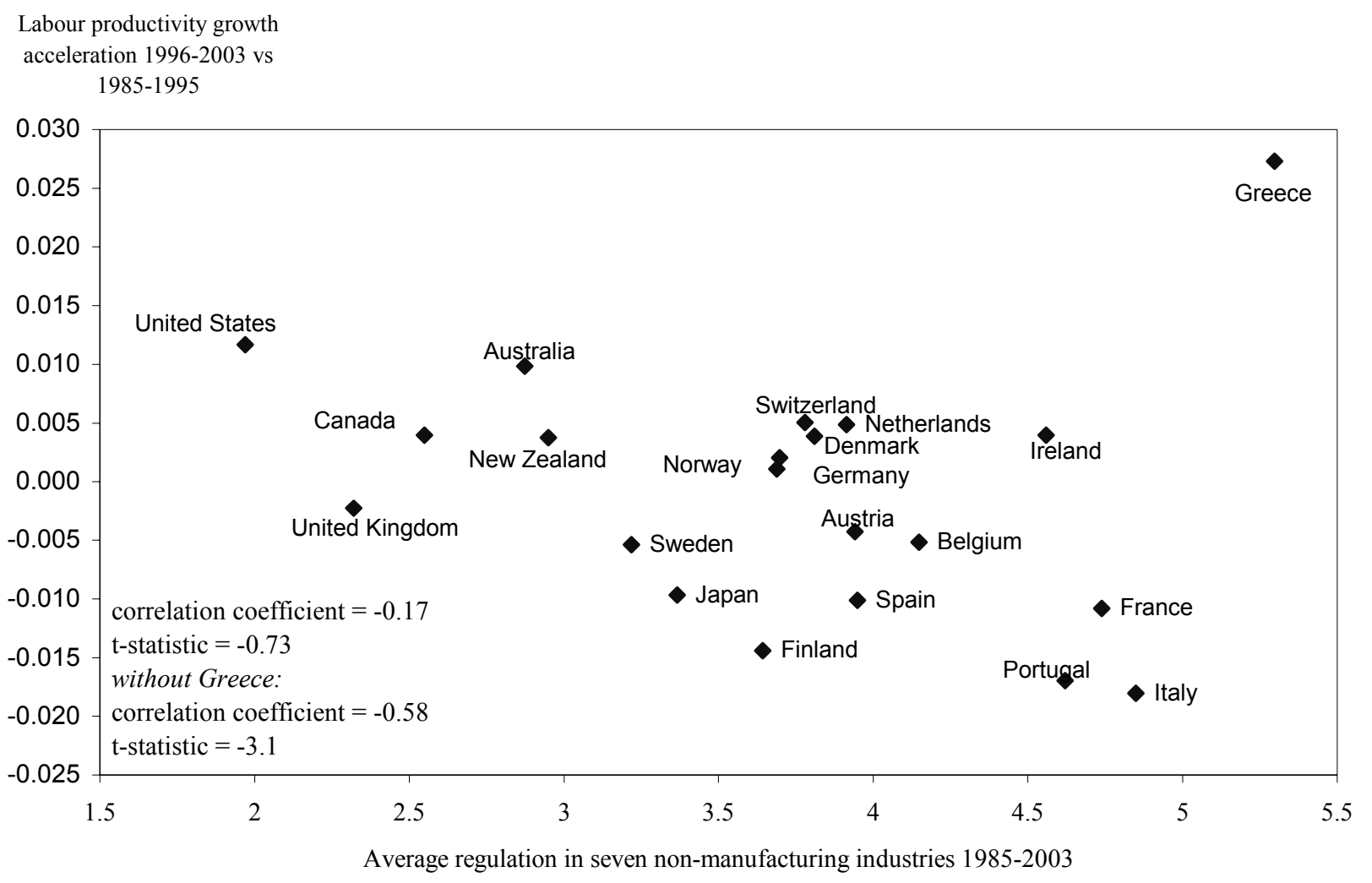

Source: OECD Productivity Database and OECD International regulation database 
Figure 8 . The effect of regulation on the diffusion of a positive supply shock ${ }^{1}$

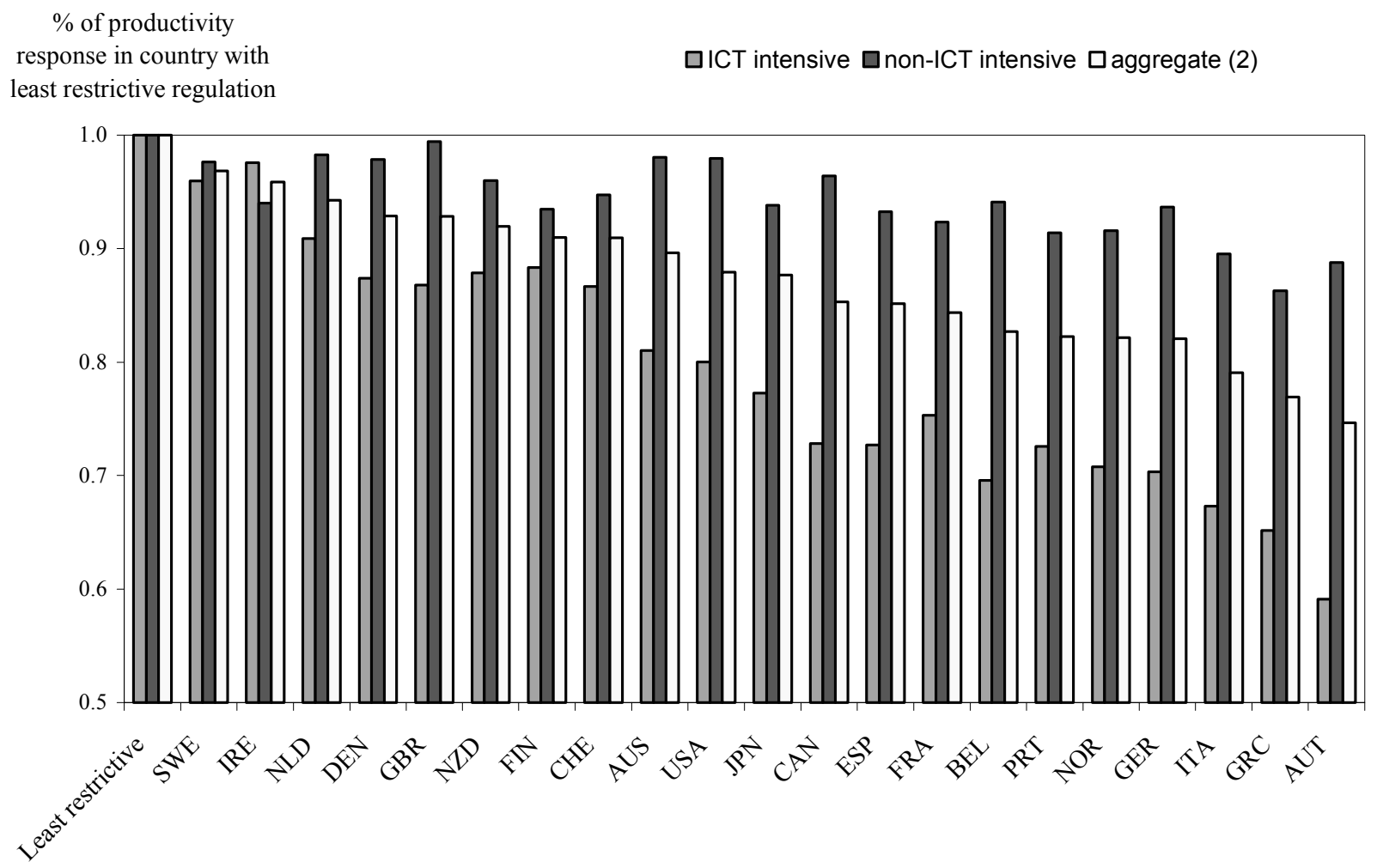

1. The increase in the level of aggregate and sectoral productivity 5 years after a positive supply shock to the world technological frontier of an equal magnitude in each sector. The data are expressed as a percentage of the response that would occur in a country with regulation that is least restrictive of competition.

2. Productivity is derived as the average of industry-level productivities weighted with value-added weights. 
Figure 9. Standard deviation of labour productivity across countries following a global supply shock:

\section{ICT and non-ICT intensive sectors ${ }^{1}$}

standard deviation

(x1000)

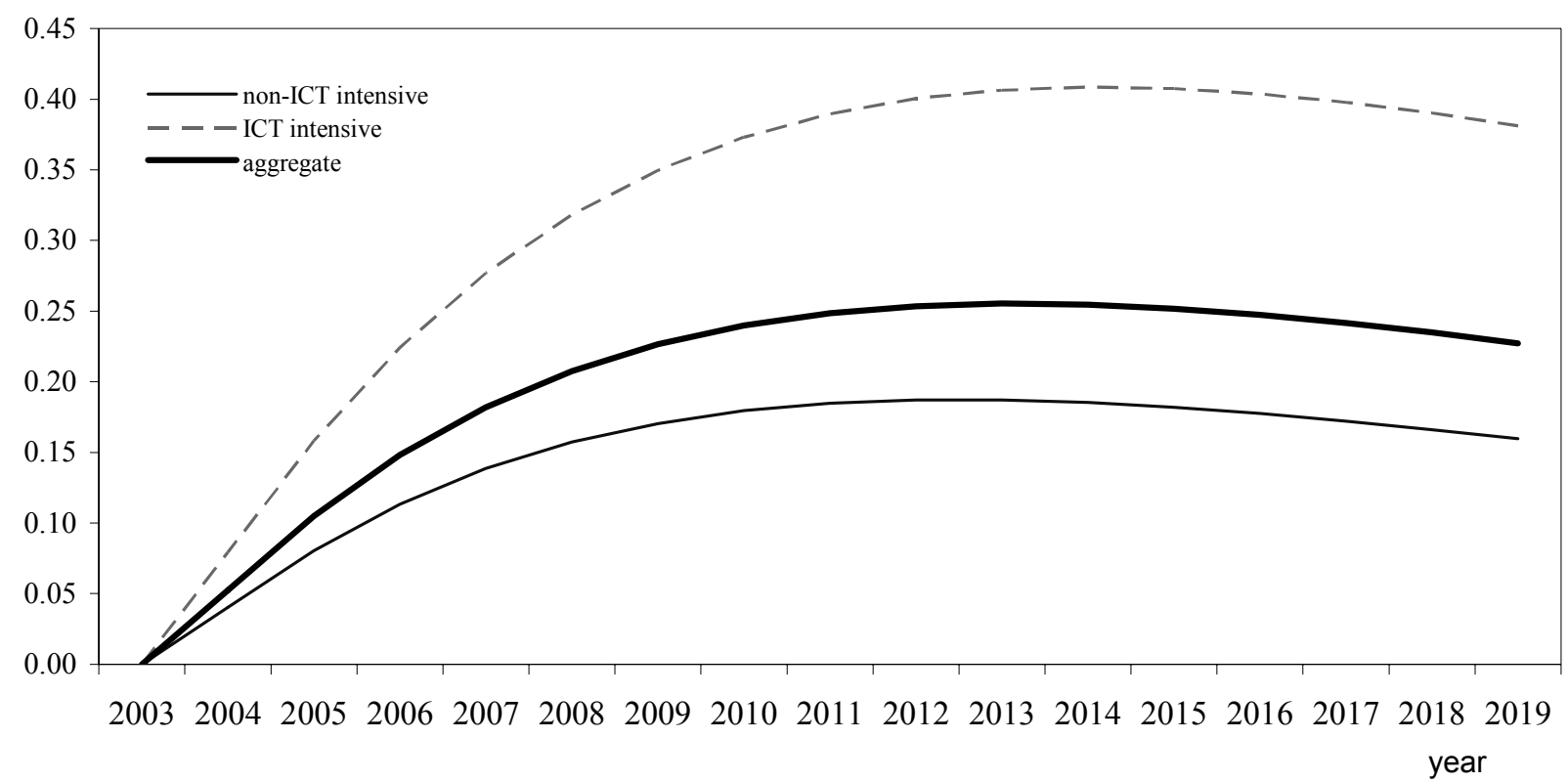

1 The standard deviation of the level of labour productivity across countries following a positive supply shock in 2003 . 
Figure 10. Increase in average annual business sector productivity growth over the period 1995 to 2003 given a move to sectoral regulations that are least restrictive of competition in $1995^{1}$

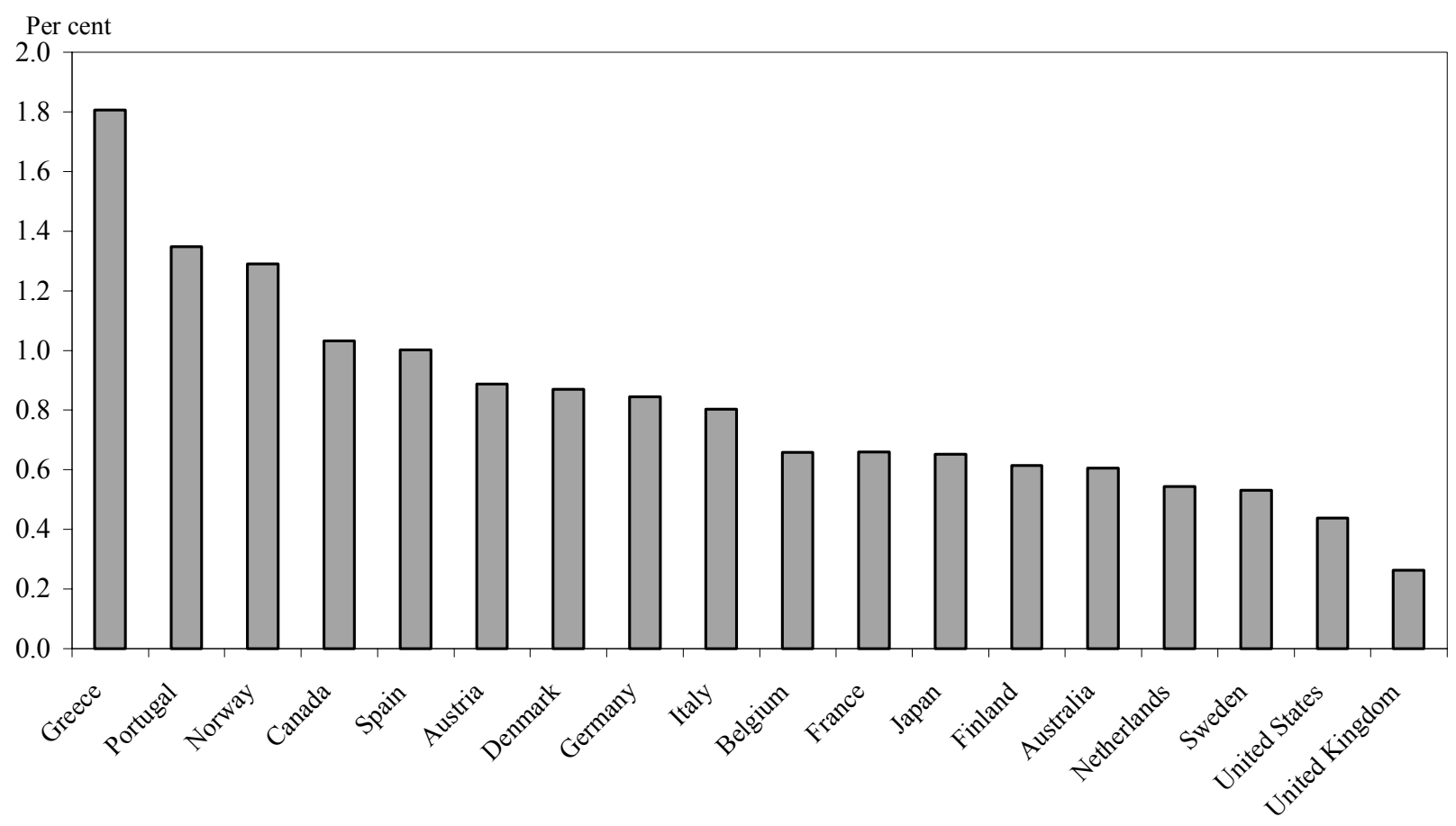

1. Data are the average increase in annual business-sector productivity over the period 1995 to 2003 given an easing in regulation to the least restrictive of competition in non-manufacturing sectors in OECD countries in 1995. Productivity in the productivity leader in each sector is assumed to grow at $1.6 \%$ per year. The business-sector results are calculated as weighted averages of the sectoral productivity increases using value added weights. 
Figure 11. Increase in average annual productivity growth over the period 1995 to 2003 given a move to sectoral regulations that are least restrictive of competition:

\section{ICT-intensive and non-ICT intensive sectors ${ }^{1}$}

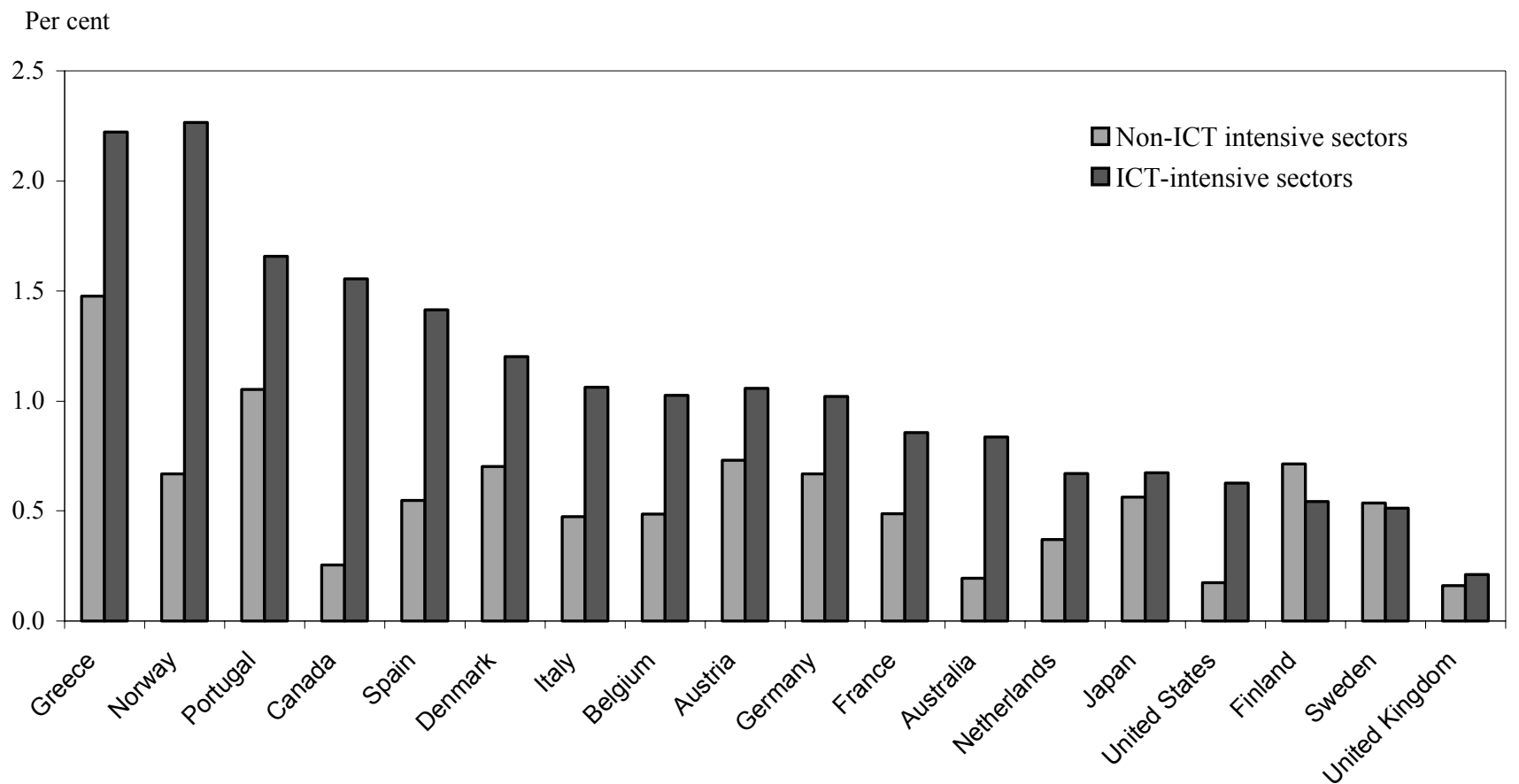

1. Data are the average increase in annual productivity following an easing in regulation to the least restrictive of competition in OECD countries in each sector. Productivity in the productivity leader in each sector is assumed to grow at $1.6 \%$ per year. The results are calculated as weighted averages of the sectoral productivity increases using value added weights. 


\section{$\mathrm{ECO} / \mathrm{WKP}(2006) 37$}

Figure 12. The standard deviation of labour productivity across countries actual and in a reform scenario ${ }^{1}$

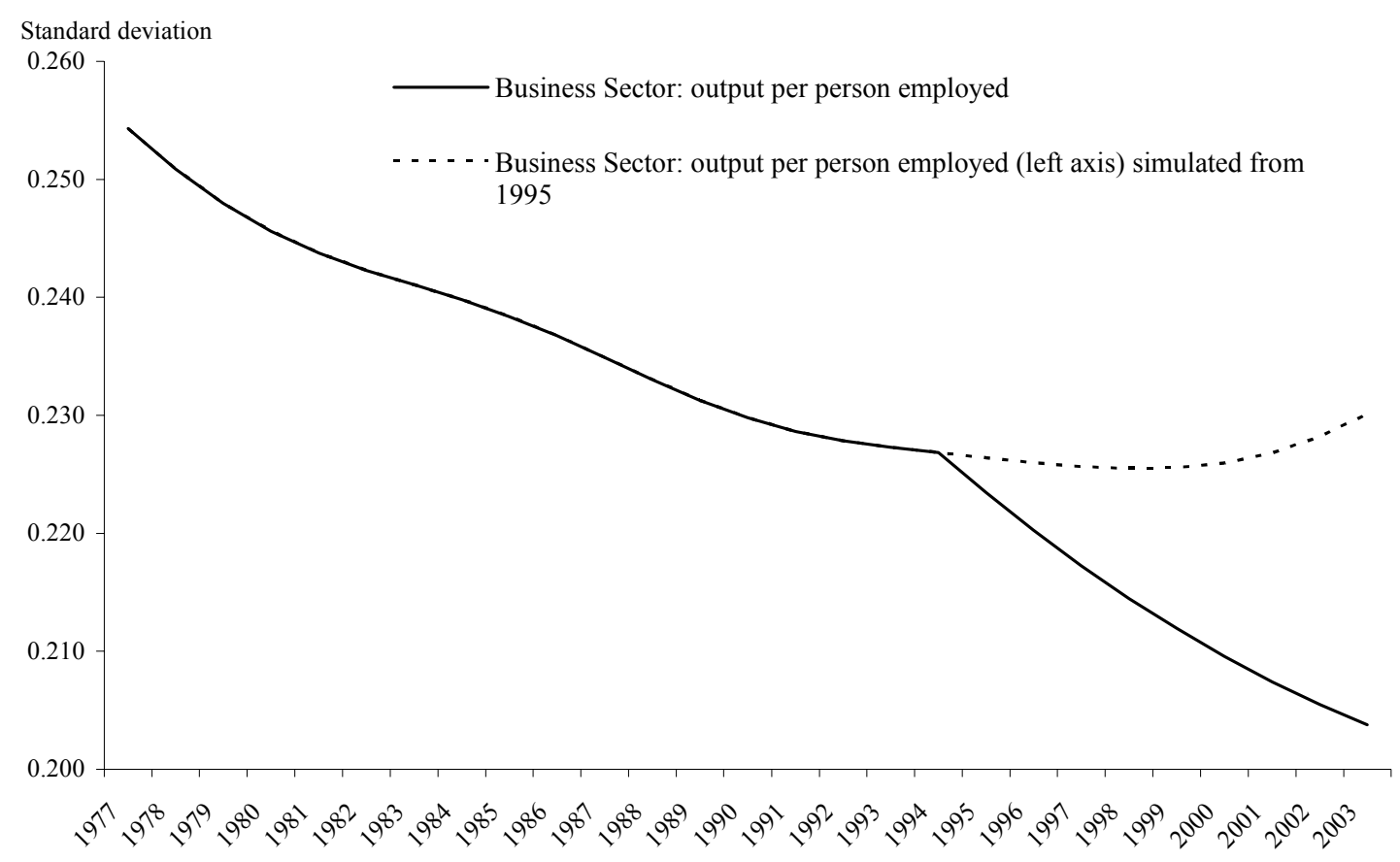

1 Calculated using cyclically-adjusted series of output and employment in business sector industries for 21 OECD countries (HodrickPrescott filter, lambda $=100$, data extended to 2006 using OECD medium-term projections to mitigate the end-point problem inherent with this filter). The simulated results are derived on the basis of countries adopting the regulatory framework of the least restrictive OECD country in non-manufacturing sectors in 1995.

Source: OECD 
Figure 13. The diffusion of information communication technology 1

(share of ICT investment in total non-residential fixed capital formation)

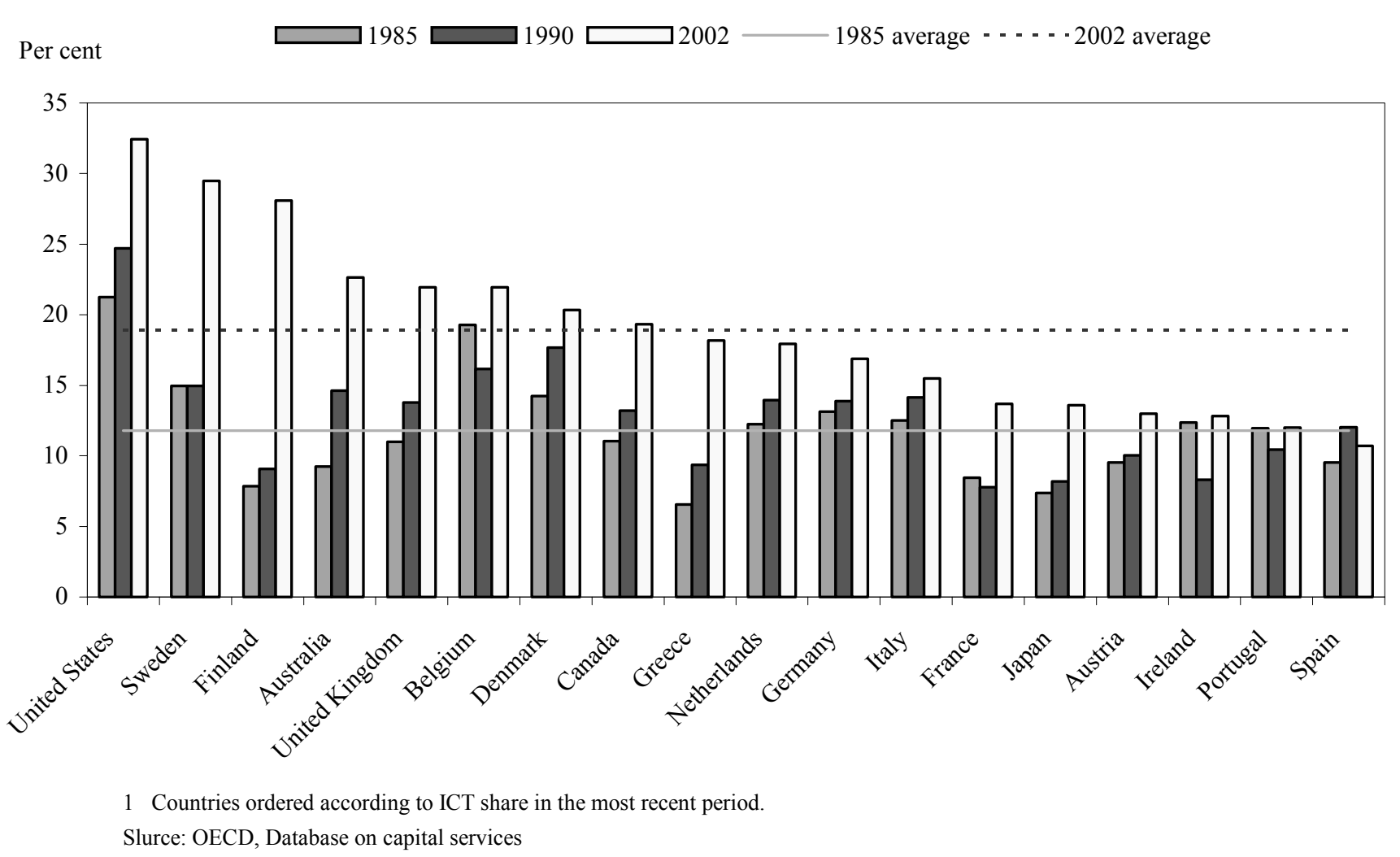


Figure 14. Product market regulation and the diffusion of information communication technology ${ }^{1}$

The scale of the indicators is 0-6 from least to most restrictive

Average ICT investment

(\% total investment)

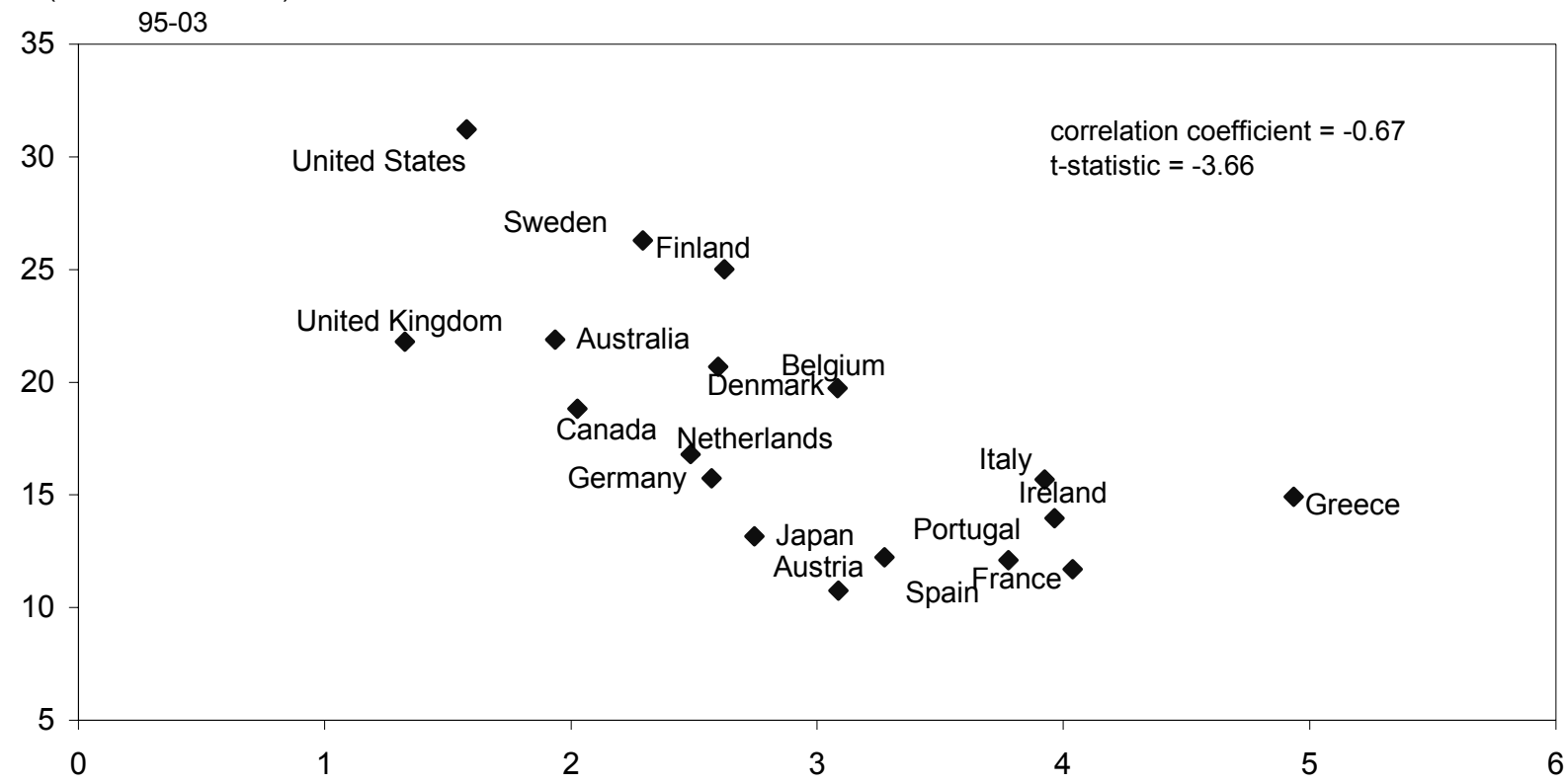

Average regulation in ICT-using sectors, 95-03

1 The indicator of regulation in ICT-using sectors is the simple average of the 'regulation impact' indicators for the individual industries included in these sectors. 
Figure 15. Contributions to the deviation of the share of ICT in total investment from the OECD average, 1985-2003 ${ }^{1}$

\section{Deviation from OECD average over the full sample period}

OECD average share $=15.5 \%$
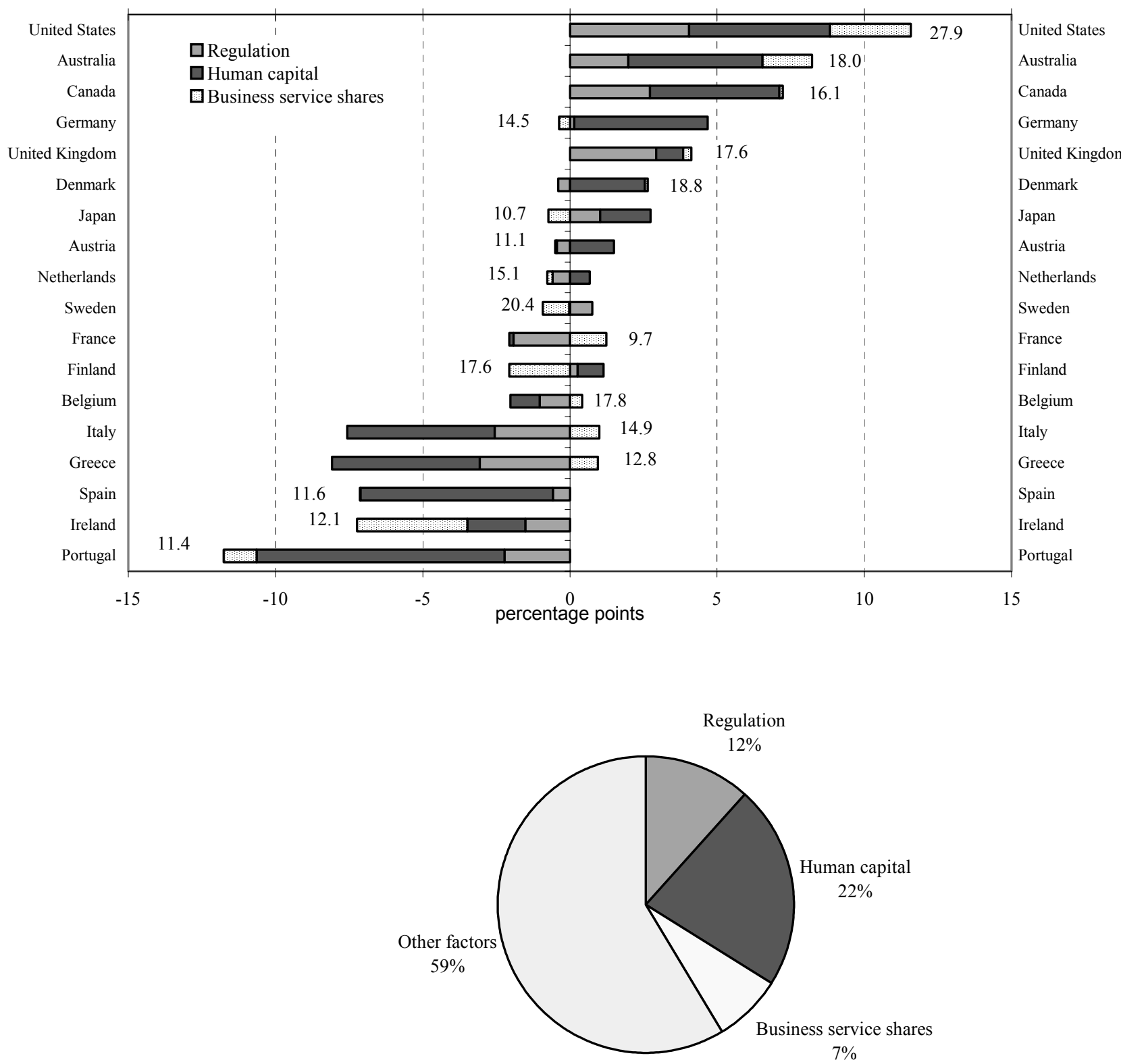

Average contributions in the OECD area

1 These contributions have been calculated using the results of the aggregate ICT regression reported in column 4 of Table $2 \mathrm{~A}$. Numbers above the bars report actual shares once the contribution of other factors (including country fixed effects) has been accounted for. Countries are ordered according to the sum of the different contributions. 
Figure 16. Increase in ICT investment share following a move to product market regulation that is least restrictive of competition ${ }^{1}$

Panel A: Countries for which data on ICT investment are available

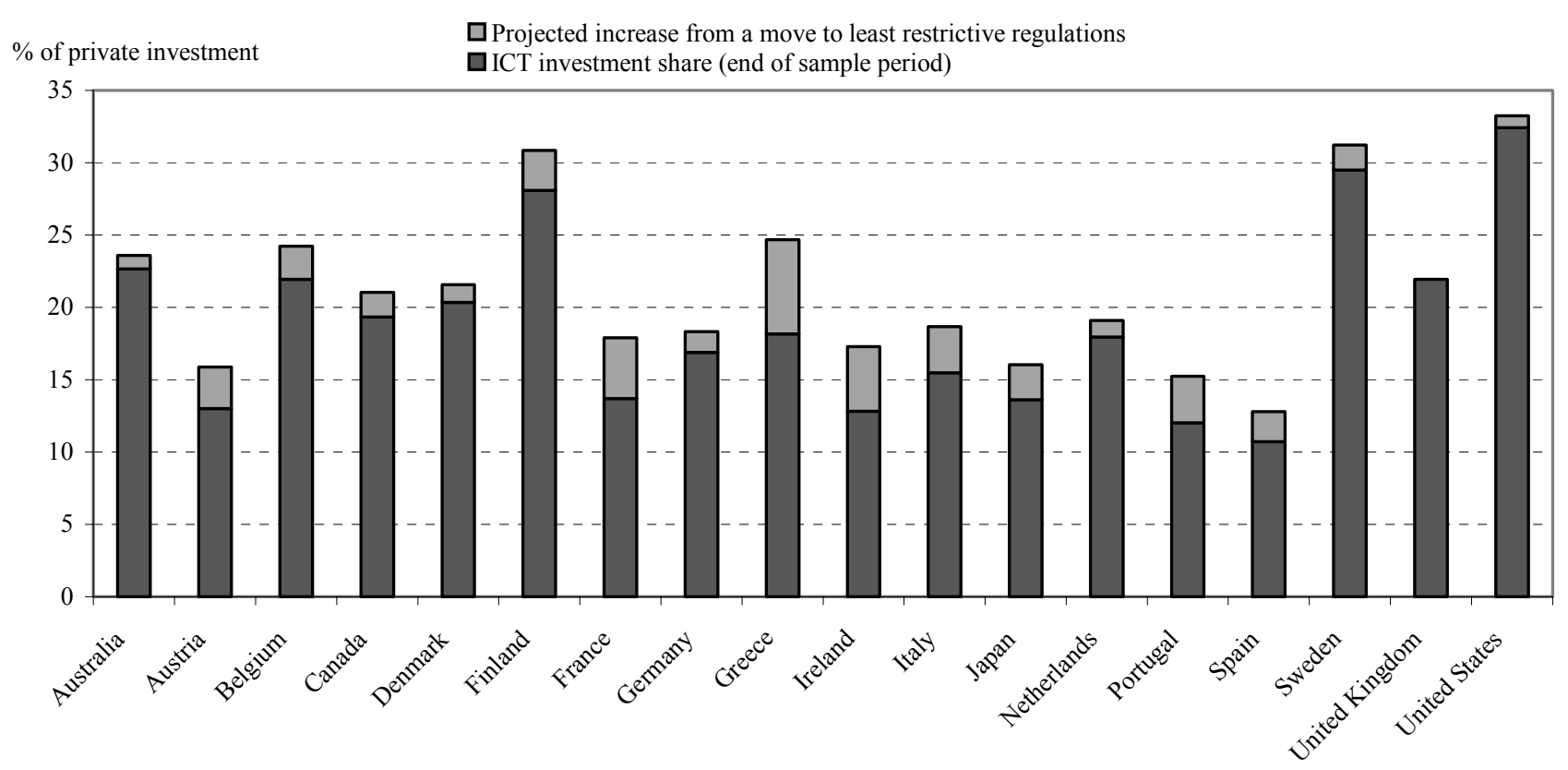

Panel B: Countries for which data on ICT investment are missing ${ }^{2}$

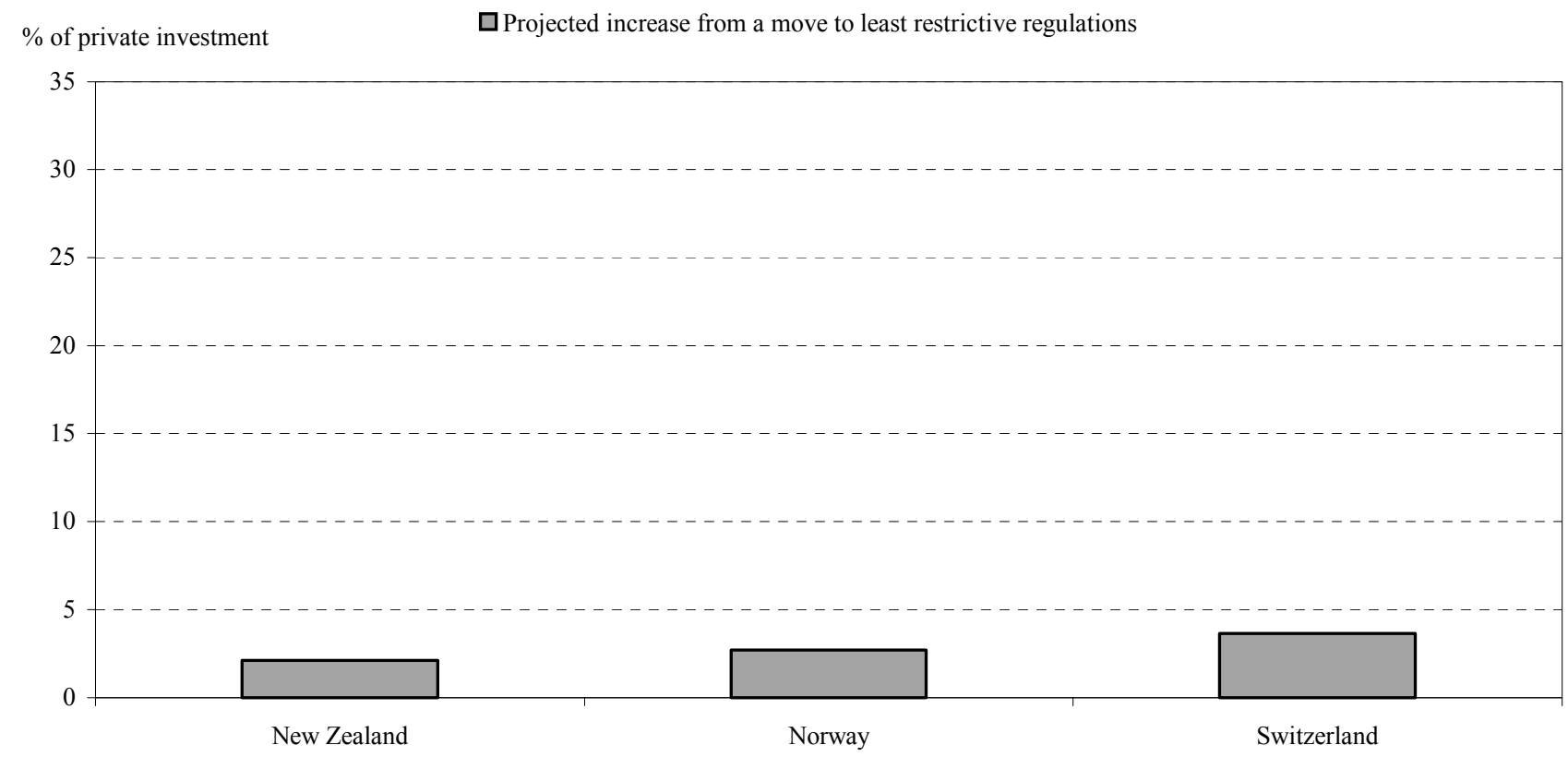

1 These results have been calculated using the aggregate ICT regression reported in column 4 of Table 2A. The United Kingdom is estimated to have the lowest overall level of anti-competitive regulation in 2003 according to the aggregate indicators of regulation in seven non-manufacturing industries used in this simulation.

2 Estimated percentage point increase in countries for which data on ICT investment are not available. These estimates are based on the assumption that the average coefficients estimated for the countries in Panel A are representative of the reaction of the ICT investment share in countries outside the estimation sample. 
Figure 17. Employment share of foreign affiliates in the manufacturing sector ${ }^{1}$

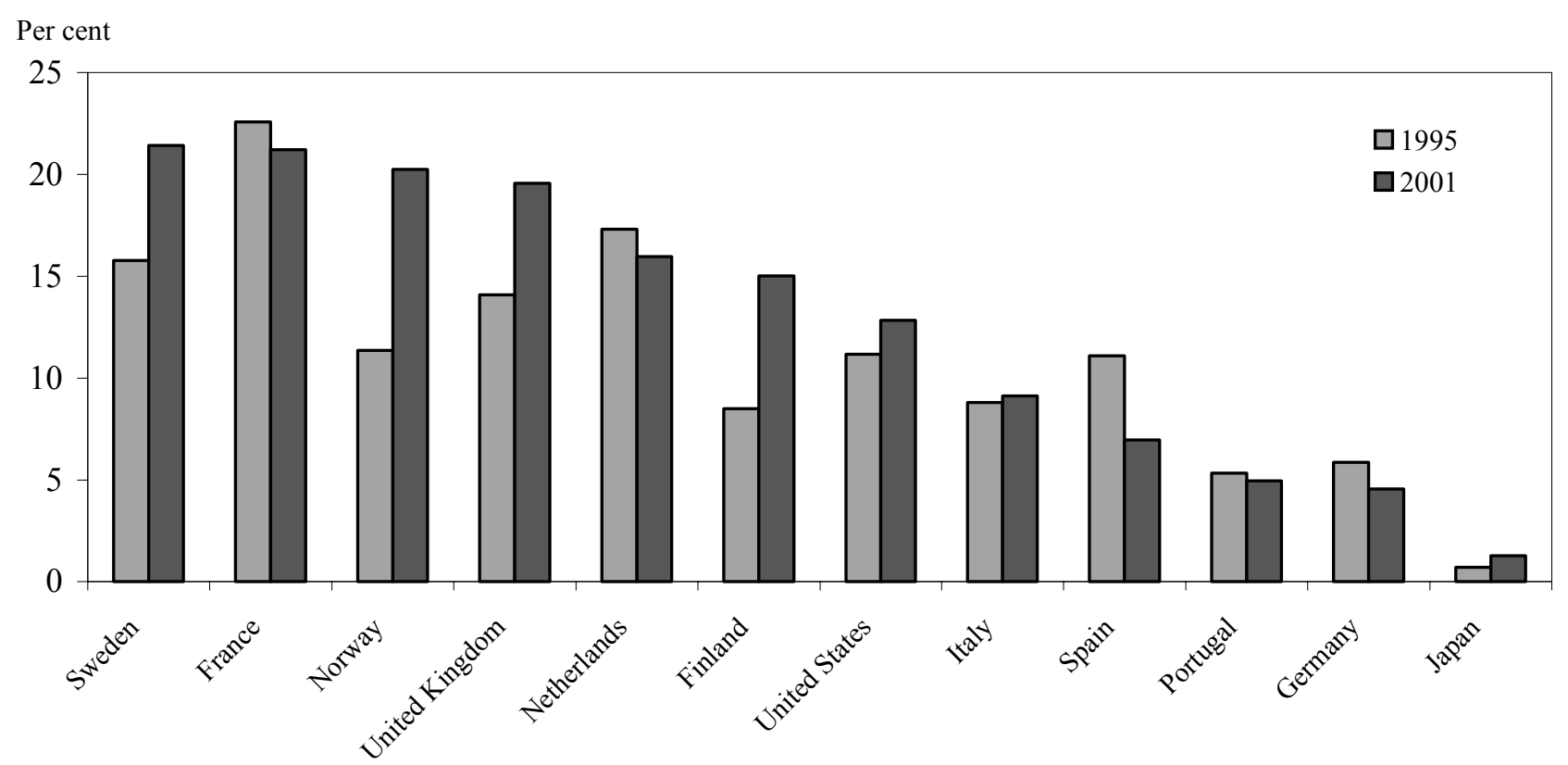

1 Weighted average of manufacturing industries based on the employment shares in the OECD STAN sectoral database. Due to missing data at the sectoral level, cross-country comparisons should be interpreted with caution. See the Annex and Criscuolo (2005) for a description of these data.

Source: OECD 
Figure 18. Product market regulation and the employment share of foreign affiliates in manufacturing, 1995-2003

Indicator of regulation

impact in manufacturing

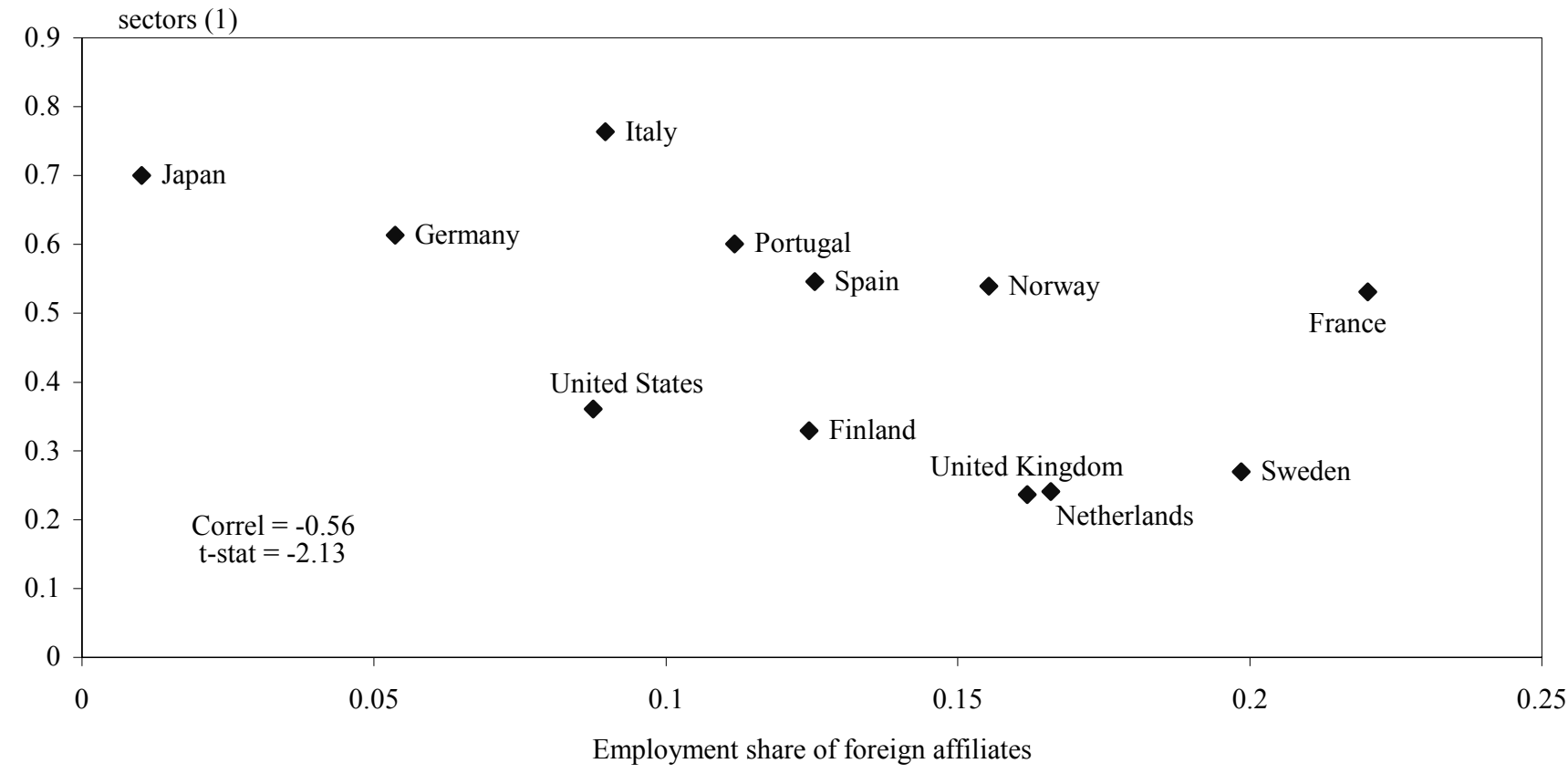

1 Simple average of the regulation impact indicators for manufacturing industries.

Source: OECD 


\section{Figure 19. Contributions to the deviation of the employment share of foreign affiliates from the OECD average, 1995-2003 ${ }^{1}$}

Deviation from OECD average over the full sample period OECD average share $=9.9 \%$

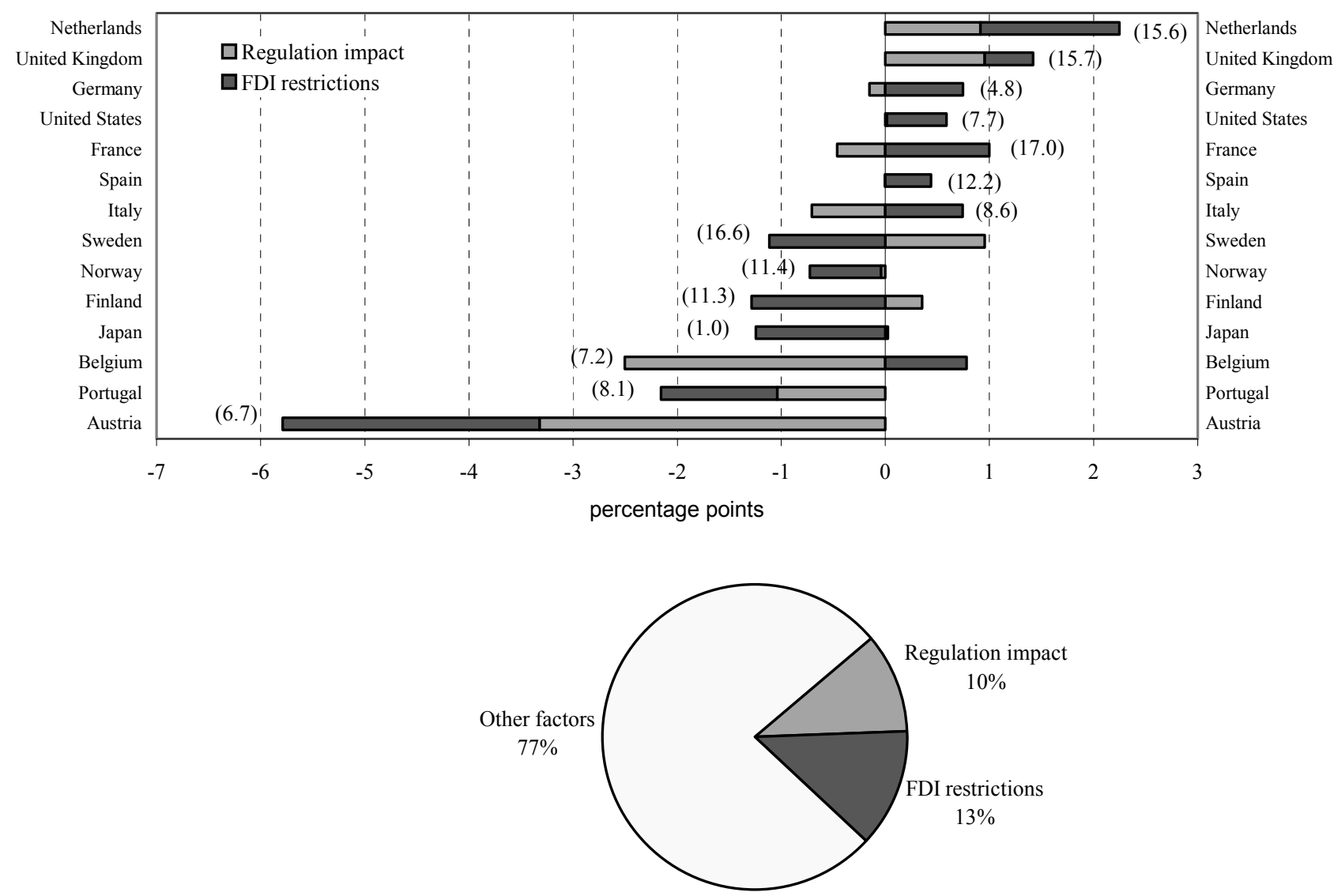

Average contributions in the OECD area

1 These contributions have been calculated using the results of the foreign affiliate regression reported in column 5 of Table 4 . Numbers in parenthesis report actual shares once the contribution of other factors (including country fixed effects) has been accounted for. Countries are ordered according to the sum of the different contributions. 
Figure 20. Increase in the employment share of foreign affiliates following a move to sectoral regulations and FDI restrictions that are least restrictive of competition ${ }^{1}$

Panel A: Countries for which data on employment shares are available

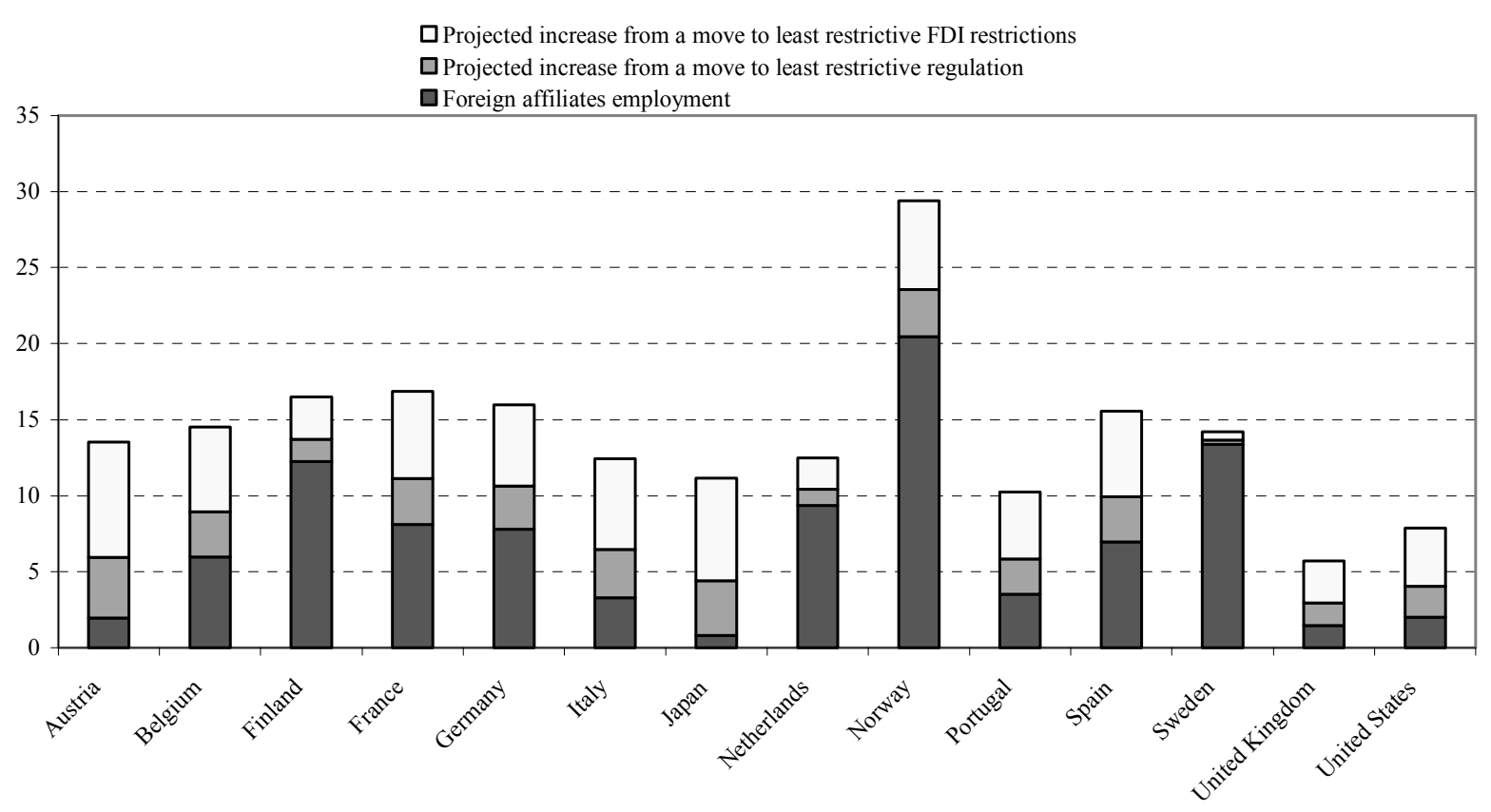

Panel B: Countries for which data on employment shares are missing ${ }^{2}$

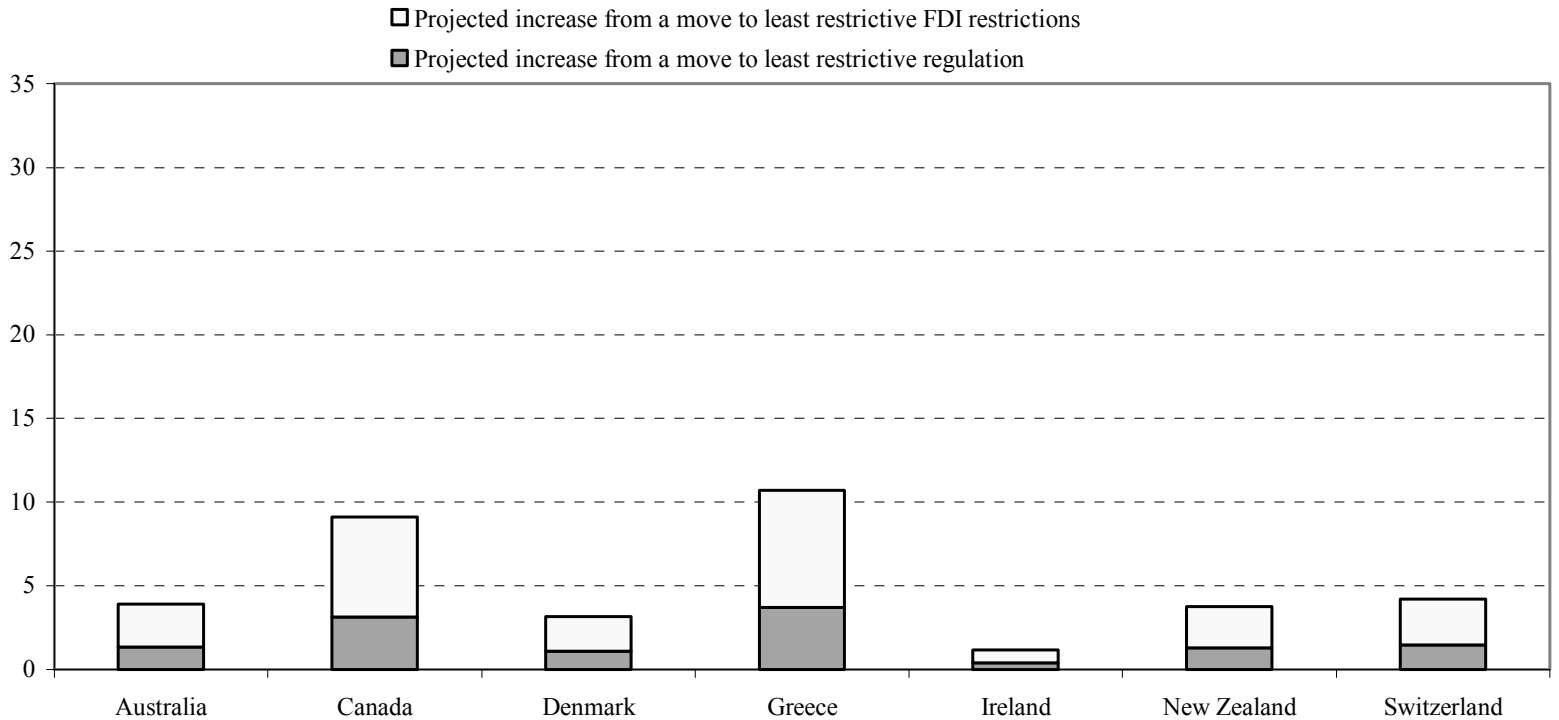

1 Derived using the regression results reported in column 5 of Table 4.4, the figure shows the effect of a loosening in regulation and FDI restrictions to the level of the least restrictive country in all sectors. The numbers in this graph are the weighted averages of the sectoral increases in the employment share of foreign affiliates over the sectors for which data exist in each country. Because of limitations in the coverage of the underlying data these results should be treated as indicative. 2 Estimated percentage point increase in countries for which data on foreign affiliates are not available.

These estimates are based on the assumption that the average coefficients estimated for the countries in Panel A are representative of the reaction of foreign affiliates in countries outside the estimation sample. 


\section{WORKING PAPERS}

The full series of Economics Department Working Papers can be consulted at www.oecd.org/eco/Working_Papers/

508. Improving education achievement and attainment in Luxembourg to compete in the labour market (September 2006) David Carey and Ekkehard Ernst

507. Raising economic performance by fostering product market competition in Germany (August 2006) Andrés Fuentes, Eckhard Wurzel and Andreas Reindl

506. Regulation of financial systems and economic growth (August 2006) Alain de Serres, Shuji Kobayakawa, Torsten Sløk and Laura Vartia

505. Enhancing Portugal's human capital

(August 2006) Bénédicte Larre and Stéphanie Guichard

504. Improving labour market performance in France Améliorer la performance du marché du travail en France (July 2006) Stéphanie Jamet

503. Wage setting in Finland: Increasing flexibility in centralised wage agreements (July 2006) Åsa Johansson

502. Taxation, business environment and FDI location in OECD countries (July 2006) Dana Hajkova, Giuseppe Nicoletti, Laura Vartia and Kwang-Yeol Yoo

501. The political economy of structural reform: Empirical evidence from OECD countries (July 2006) Jens Høj, Vincenzo Galasso, Giuseppe Nicoletti and Thai-Thanh Dang

500. Labour market performance, income inequality and poverty in OECD countries (July 2006) Jean-Marc Burniaux, Flavio Padrini and Nicola Brandt

499. Improving Public-Spending Efficiency in Czech Regions and Municipalities (July 2006) Philip Hemmings

498. Policies to Promote Innovation in the Czech Republic (July 2006) Alessandro Goglio

497. Getting Education Right for Long-Term Growth in the Czech Republic (July 2006) Alessandro Goglio

496. Assessing the 2005 Czech Proposals for Pension Reform (July 2006) Philip Hemmings and Edward Whitehouse

495. Poland's Education and Training: Boosting and Adapting Human Capital (July 2006) Paul O’Brien and Wojciech Paczynski

494. The Rates and Revenue of Bank Transaction Taxes (July 2006) Jorge Baca-Campodónico, Luiz de Mello and Andrei Kirilenko

493. Nothing Ventured, Nothing Gained: The Long-Run Fiscal Reward of Structural Reforms (July 2006) Peter Hoeller and Claude Giorno

492. Ireland's Housing Boom: What has Driven It and Have Prices Overshot? (June 2006) Dave Rae and Paul van den Noord 


\section{$\mathrm{ECO} / \mathrm{WKP}(2006) 37$}

491. Boosting Competition in Ireland

(June 2006) Dave Rae, Line Vogt and Michael Wise

490. Factors Behind Low Long-Term Interest Rates

(June 2006) Rudiger Ahrend, Pietro Catte and Robert Price

489. The Fiscal Challenge in Portugal

(June 2006) Stéphanie Guichard and Willi Leibfritz

488. Are House Prices Nearing a Peak? A Probit Analysis for 17 OECD Countries (June 2006) Paul van den Noord

487. Maintaining Switzerland's Top Innovation Capacity

(June 2006) Florence Jaumotte

486. Employment Patterns in OECD Countries: Reassessing the Role of Policies and Institutions (June 2006) Andrea Bassanini and Romain Duval

485. Brazil’s Fiscal Stance During 1995-2005: The Effect of Indebtedness on Fiscal Policy Over the Business Cycle

(May 2006) Luiz de Mello and Diego Moccero

484. Realising the Oil Supply Potential of the CIS: The Impact of Institutions and Policies (May 2006) Rudiger Ahrend and William Tompson

483. Summary of a workshop on global convergence scenarios: structural and policy issues (May 2006) Nick Vanston

482. Revised OECD methods for supply-side and medium-term assessment: a capital services approach (July) Pierre-Olivier Beffy, Patrice Ollivaud, Pete Richardson and Frank Sédillot

481. Balancing health care quality and cost containment: the case of Norway (February 2006) Alexandra Bibbee and Flavio Padrini

480. The ageing challenge in Norway: ensuring a sustainable pension and welfare system (February 2006) Benoît Bellone and Alexandra Bibbee

479. Strengthening innovation in the Netherlands: Making better use of knowledge creation in innovation activities (February 2006) David Carey, Ekkehard Ernst, Rebecca Oyomopito and Jelte Theisens

478. How to sustain growth in a resource based economy? The main concepts and their application to the Russian case

(February 2006) Rudiger Ahrend

477. Projecting OECD health and long-term care expenditures: What are the main drivers? (February 2006)

476. Alternative measures of well-being (January 2006) Romina Boarini, Åsa Johansson and Marco Mira D'Ercole

475. Recent house price developments: the role of fundamentals

(January 2006) Nathalie Girouard, Mike Kennedy, Paul van den Noord and Christophe André

474. Reforming federal fiscal relations in Austria

(January 2006) Andrès Fuentes, Eckhard Wurzel and Andreas Wörgötter 